\title{
The Sex-Related Interplay between TME and Cancer: On the Critical Role of Estrogen, MicroRNAs and Autophagy
}

\author{
Paola Matarrese ${ }^{1,+}{ }^{+D}$, Gianfranco Mattia ${ }^{1,+}{ }^{+}$, Maria Teresa Pagano ${ }^{1}$, Giada Pontecorvi ${ }^{1}$, Elena Ortona ${ }^{1}$, \\ Walter Malorni ${ }^{2,3, *}$ and Alessandra Carè ${ }^{1}$ \\ 1 Center for Gender Specific Medicine, Istituto Superiore di Sanità, 00161 Rome, Italy; \\ paola.matarrese@iss.it (P.M.); gianfranco.mattia@iss.it (G.M.); mariateresa.pagano@guest.iss.it (M.T.P.); \\ giada.pontecorvi@iss.it (G.P.); elena.ortona@iss.it (E.O.); alessandra.care@iss.it (A.C.) \\ 2 Department of Biology, Faculty of Farmacy, University of Rome Tor Vergata, 00133 Rome, Italy \\ 3 Center for Global Health, Università Cattolica del Sacro Cuore, 00168 Rome, Italy \\ * Correspondence: walter.malorni@unicatt.it \\ + These authors are first co-authors for this work.
}

check for

updates

Citation: Matarrese, P.; Mattia, G.; Pagano, M.T.; Pontecorvi, G.; Ortona, E.; Malorni, W.; Carè, A. The Sex-Related Interplay between TME and Cancer: On the Critical Role of Estrogen, MicroRNAs and Autophagy. Cancers 2021, 13, 3287. https://doi.org/10.3390/

cancers13133287

Academic Editor: Francesca Bianchin

Received: 16 May 2021

Accepted: 25 June 2021

Published: 30 June 2021

Publisher's Note: MDPI stays neutral with regard to jurisdictional claims in published maps and institutional affiliations.

Copyright: (c) 2021 by the authors. Licensee MDPI, Basel, Switzerland. This article is an open access article distributed under the terms and conditions of the Creative Commons Attribution (CC BY) license (https:/ / creativecommons.org/licenses/by/ $4.0 /)$.
Simple Summary: Autophagy is a complex cell process that allow the cell to survive in unfavorable conditions, e.g., in the lack of nutritional elements coming from the environment. Here we focused on the role played by autophagy in the crosstalk between the microenvironment surrounding the tumor and cancer cells. This environment is in fact known as pivotal in determining the growth or the inhibition of a tumor. Cancer progression and response to therapy significantly differ between women and men and the microenvironment, in particular sex hormones and microRNAs, appears a critical factor. Four representative types of cancer, i.e., colon cancer, melanoma, lymphoma, and lung cancer showing sex/gender specificities have been described herein. We underscore that the use of a "gender tailored" approach could provide a better comprehension of the cellular and molecular mechanisms of cancer growth control contributing to the development of novel therapeutic approaches towards an increasingly personalized medicine.

Abstract: The interplay between cancer cells and the tumor microenvironment (TME) has a fundamental role in tumor progression and response to therapy. The plethora of components constituting the TME, such as stroma, fibroblasts, endothelial and immune cells, as well as macromolecules, e.g., hormones and cytokines, and epigenetic factors, such as microRNAs, can modulate the survival or death of cancer cells. Actually, the TME can stimulate the genetically regulated programs that the cell puts in place under stress: apoptosis or, of interest here, autophagy. However, the implication of autophagy in tumor growth appears still undefined. Autophagy mainly represents a cyto-protective mechanism that allows cell survival but, in certain circumstances, also leads to the blocking of cell cycle progression, possibly leading to cell death. Since significant sex/gender differences in the incidence, progression and response to cancer therapy have been widely described in the literature, in this review, we analyzed the roles played by key components of the TME, e.g., estrogen and microRNAs, on autophagy regulation from a sex/gender-based perspective. We focused our attention on four paradigmatic and different forms of cancers-colon cancer, melanoma, lymphoma, and lung cancer-concluding that sex-specific differences may exert a significant impact on TME/cancer interaction and, thus, tumor growth.

Keywords: cancer; gender; sex; sex hormones; microRNA; autophagy; tumor microenvironment

\section{Introduction \\ 1.1. Tumor Microenvironment}

It has long been known that a tumor mass is constituted by cancer cells and by several other cell types such as smooth muscle cells, endothelial cells, fibroblasts, lymphocytes, 
macrophages, and, especially in some types of cancer, adipocytes. These cells dynamically interact with the tumor cells and with the components of the extracellular matrix (ECM) to constitute the tumor microenvironment (TME), which significantly contributes to tumor progression [1]. Through humoral factors, such as cytokines, chemokines, hormones, and active metabolites, microRNAs (miRs), and mechanical stimuli, e.g., those mediated by cell adhesion features, TME can exert a critical function by co-stimulating (or co-inhibiting) the clonal selection, thus leading to a metastatic or drug-resistant phenotype as well as contributing to cancer-associated angiogenesis [2]. For instance, tumor-associated macrophages (TAM) and cancer-associated fibroblasts (CAF) can interact with each other and with tumor cells through paracrine mechanisms to produce a tumor-promoting microenvironment. Hence, the TME could be involved in all stages of tumor progression, including epithelial-mesenchymal transition (EMT), migration and invasion, extravasation and colonization at the secondary site of metastasis [3]. Currently, the TME characteristics represent a hallmark of cancer, often with predictive value [4]. The cells embedded in the tumor stroma also play a fundamental role as metabolic support for tumor cells. For example, as a consequence of their metabolic reprogramming induced by cancer cells, the aerobic glycolysis of stromal cells would provide the latter, in addition to ATP, with various metabolites, which are instrumental to the production of further ATP through OXPHOS. In addition, a phagocytic cannibalic behavior exerted by cancer cells could also provide further nutrients to cancer cells $[5,6]$. This metabolic coupling between stromal and tumor cells would also allow the exchange of metabolites, which are suitable to tumor cells in terms of increasing their proliferation and reducing cell death. This phenomenon is known as the Reverse Warburg Effect [7].

In Figure 1, a simplified scheme of the main cellular and non-cellular components of the TME involved in tumor progression through multiple intercellular signals is reported.

\subsection{Autophagy}

As the TME is often hypoxic and sometimes scarce of nutrients, cancer cells counteract this detrimental issue by activating an elusive survival process, i.e., autophagy, thus adapting to these unfavorable environmental conditions [8]. Autophagy (more precisely the process called macroautophagy) is a homeostatic, highly conserved, genetically driven process by which macromolecules and organelles can be degraded and recycled within the cells. It is a cytoprotective process driven by specific genes: the autophagy genes (ATGs) [9]. Thirty-six proteins produced by these genes, the ATG proteins, have been identified so far in yeast, each with a respective orthologue detectable in mammalian cells. In normal non-transformed cells, autophagy represents a protective mechanism that can be increased in the case of lack of nutrients or in the presence of cell-damaging stressors. Notably, it has been suggested that autophagy inhibition in non-transformed cells could contribute to cancerogenesis [10] or that it can play an essential role in promoting tumor cell survival, by also conferring resistance to anticancer drugs [11] and favoring survival of dormant cancer cells [12]. The interplay between TME and autophagy is thus pivotal. For instance, the hypoxic and anoxic conditions of the TME have been shown to induce autophagy via the $5^{\prime}$ adenosine monophosphate-activated protein kinase (AMPK), the PKR-like ER kinase (PERK), and the Hypoxia-Inducible Factor 1-alpha (HIF-1 $\alpha$ )/Forkhead box O3 (FOXO3) signaling pathways [13]. Furthermore, inflammation, often associated with tumor progression, can induce autophagy, mainly through the activity of the nuclear factor kappa B (NF-kB), a major player involved in the inflammatory response [14].

Recently, a very selective form of autophagy, called mitophagy, has emerged as a crucial determinant at the interface between tumor cells and TME [15]. Growing evidence shows that mitophagy pathways are key regulators of mitochondrial mass, mitochondrial dynamics, redox homeostasis, metabolic reprogramming and cancer cell survival or death. Mitophagy would represent a metabolic adaptation mechanism capable of fostering the survival of cancer cells within an otherwise unfavorable microenvironment. According to this, it has been observed that many proteins involved in mitophagy are dysregulated 
in some tumors [16]. In addition to cancer cells, the mitophagy of stromal cells would promote tumor progression by providing essential compounds in the metabolism of cancer cells [17]. In accordance with the above, the induction of mitophagy by anticancer drugs could contribute to resistance to therapy, a hypothesis supported by the fact that the inhibition of mitophagy was able, in some models, to re-sensitize cancer cells to pharmacological treatment [18]. On the other hand, a reduced mitophagy increases mitochondrial reactive oxygen species (ROS) levels. The consequent oxidative stress, through HIF- $1 \alpha$ stabilization, can promote the Warburg effect, favoring tumor progression even in normoxia conditions. The Warburg effect, referred as to the production of ATP through glycolysis rather than through OXPHOS, can in turn result in lactate production and contribute to the acidification of TME, indirectly regulating tumor invasion and metastasis [19] as well as drug resistance [20]. Hence, strategies aimed at buffering the TME $\mathrm{pH}$ have also been proposed in both preclinical [21] and in clinical studies (NCT01198821) [22] whereas strategies aimed at the control of mitophagic process are still lacking.

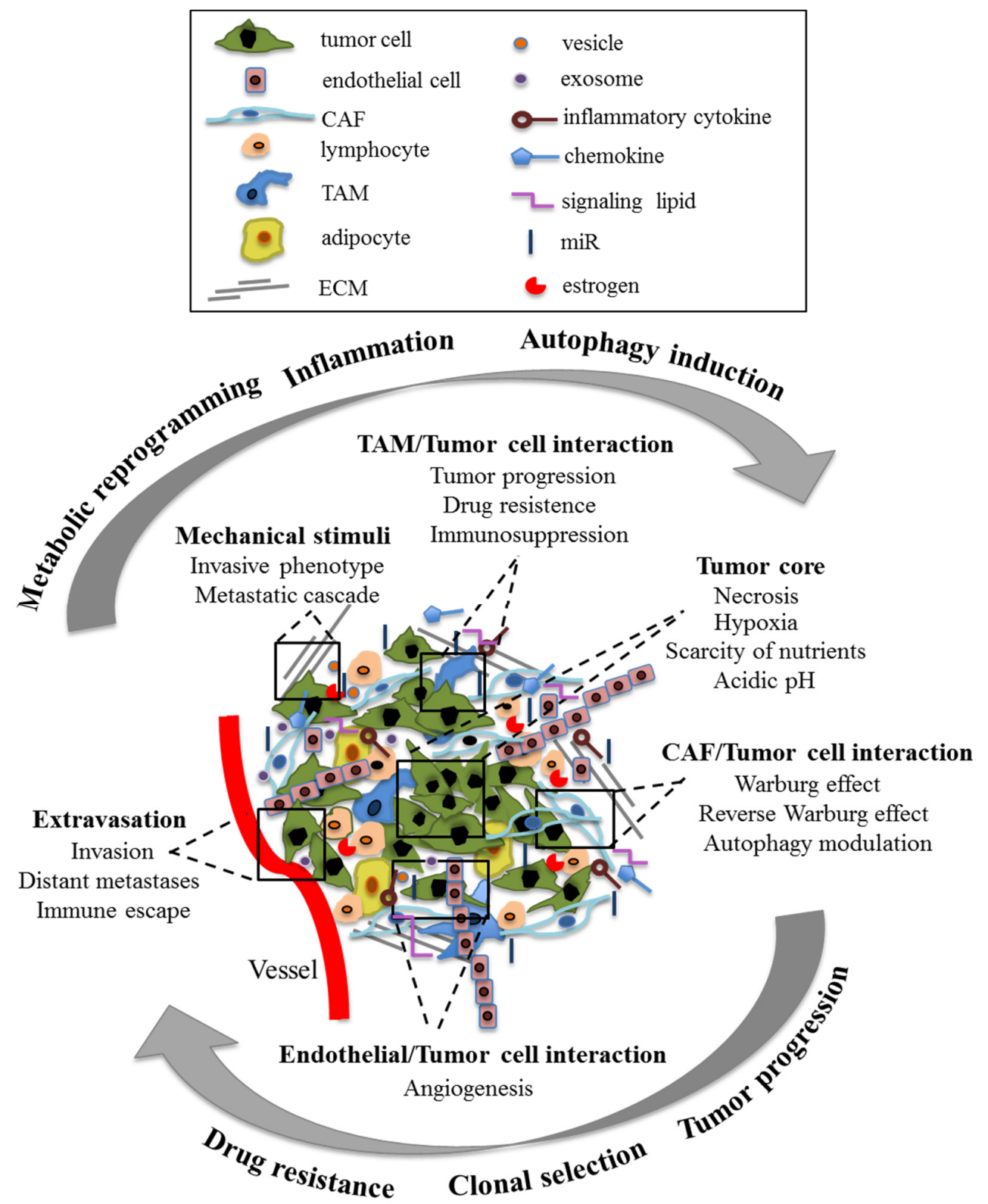

Figure 1. Simplified and exemplary illustration of the main cellular and non-cellular components of the TME that actively participate, through multiple intercellular signals, in tumor progression. 
An additional point to be considered concerns the epigenetic regulation of autophagy in cancer. Several miRs have been shown to modulate the autophagy mechanisms and the levels of some miRs regulating autophagy have been found altered in the oncology context [23]. Importantly, dysregulation of these miRs has been observed both in tumor and stromal cells, and the cross talk between tumor and stromal miRs can determine the characteristics of the TME. Of note, the miRs present in the TME are either free or enclosed within vesicles and/or exosomes, and can act both as tumor suppressors and as activators [24].

\subsection{Sex Differences in Cancer}

The third actor considered herein is related to the sex/gender disparity observed in many forms of cancers $[25,26]$. In fact, significant sex/gender differences in cancer incidence, progression, and response to therapy have been reported [26-30]. Importantly, differences in the clinical outcome have recently been reported for many types of tumors [30-32]. On the other hand, several observations were made with regard to the role of the sex of the patient on the activation of the autophagy pathway [33]. These differences are partly related to the effects of steroid hormones, especially estrogen. Moreover, some studies reported that, irrespective of steroid hormones, sex chromosomes could play a role per se. Indeed, $\mathrm{XX}$ cells appear more prone to autophagy than $\mathrm{XY}$ ones: cells from females could survive better than cells from males in unfavorable environmental conditions thanks to a higher autophagic propensity [34-38]. A detailed review has recently been published addressing sex differences in a range of autophagy-mediated diseases, including cancer. The authors correctly state that a clinical approach that takes into account differences related to the sex of subject (and gender, the socio-economical, nutritional aspects characterizing a subject) is a first step towards precision medicine [39]. Cancer therapy may be the branch of medicine closest to this innovative clinical approach.

Epigenetics is also part of this scenario. In fact, a sex-specific regulation of miRs has been suggested in many normal and pathological tissues [40]. A direct action of sex hormones, especially estrogen and progesterone, as well as of sex chromosomes [41], has been hypothesized. The $X$ chromosome contains numerous miRs (about 10\% of the total) [42] whereas the $\mathrm{Y}$ chromosome seems to contain four miRs only. The incomplete inactivation of one of the two $\mathrm{X}$ chromosomes in female cells has been proposed to represent one of the possible mechanisms underlying the sexual dimorphism observed in the expression of some X-linked miRs [43-45].

In summary, not only are the cancer cells themselves very heterogeneous, but the TME and the sex of the hosts contribute greatly to increasing the complexity of the tumor. On this basis, it has been proposed that the patient's sex and gender should be considered as an additional variable in the field of oncology, also in reference to antineoplastic treatment $[26,46]$.

In this review, we present the "state of the art" of current knowledge on the role played by autophagy in the crosstalk between the tumor cell and the microenvironment, taking into account sex differences. The roles played by steroid hormones, in particular estrogen, and miRs are considered, mainly focusing our attention on four paradigmatic not-related forms of cancer: colon cancer, melanoma, lymphoma, and lung cancer.

\section{Estrogen and Estrogen-Mediated Autophagy as Tumor and TME Key Determinants}

\subsection{Estrogen and Estrogen Receptors}

The biological effects of estrogen, the main female sex hormone, are mediated by the binding of estrogen to estrogen receptors (ERs) [47], which, besides being a crucial determinant in reproductive processes, also plays a role in many physiological processes in a number of tissues, organs and systems, such as the central nervous, cardiovascular and immune systems. In contrast to women, men are largely dependent on the local synthesis of estrogens in extragonadal target tissues, i.e., via the cytochrome P450 enzyme aromatase that catalyzes the conversion of androgens to estrogens. 
ERs belong to the steroid hormone superfamily of receptors mostly localized in the cell nucleus. In addition, ERs have also been detected at the cell surface, in the cytoplasm and at the mitochondrial level. Two different types of ERs have been identified so far: the estrogen receptor alpha $(\operatorname{ER} \alpha)[48,49]$, and the estrogen receptor beta $(E R \beta)[50,51]$.

The biological effects of estrogens are primarily carried out by the modulation of gene transcription. In fact, after binding to estrogen, ERs dimerize and migrate into the nucleus, where they bind an Estrogen Response Element (ERE). However, further estrogen signaling pathways have been demonstrated. Actually, as reported above, ERs can also be detected at the plasma membrane (mER), where they are embedded in lipid rafts (sphingolipid enriched membrane microdomains) [52]. These ERs can ignite non-genomic pathways such as the prompt activation of the mitogen-activated protein (MAP) kinase signaling pathway [53,54]. Another mER, structurally unrelated to the other ERs, but capable of inducing rapid non-genomic signals, has also been identified and named $G$ protein-coupled receptor 30 (GPR30) [55].

\subsection{Estrogen and Autophagy}

Estrogen plays a critical role in mediating many of the physiological cell functions, such as growth, differentiation, metabolism, and death. In initial studies in animal models, an increase in lysosomes and in degrading organelles was observed to be induced by castration, suggesting that sex hormones could affect autophagy $[33,56]$. These data have more recently been confirmed, demonstrating that the estrogen signaling network can stimulate autophagy [57,58] or, conversely, decrease overstimulated autophagy [59-61].

$\mathrm{ER} \alpha$ and $\mathrm{ER} \beta$ seem to play a role in regulating autophagic processes, both in cancer and TME, via a delicate and tricky process aimed at controlling cell homeostasis (Figure 2).

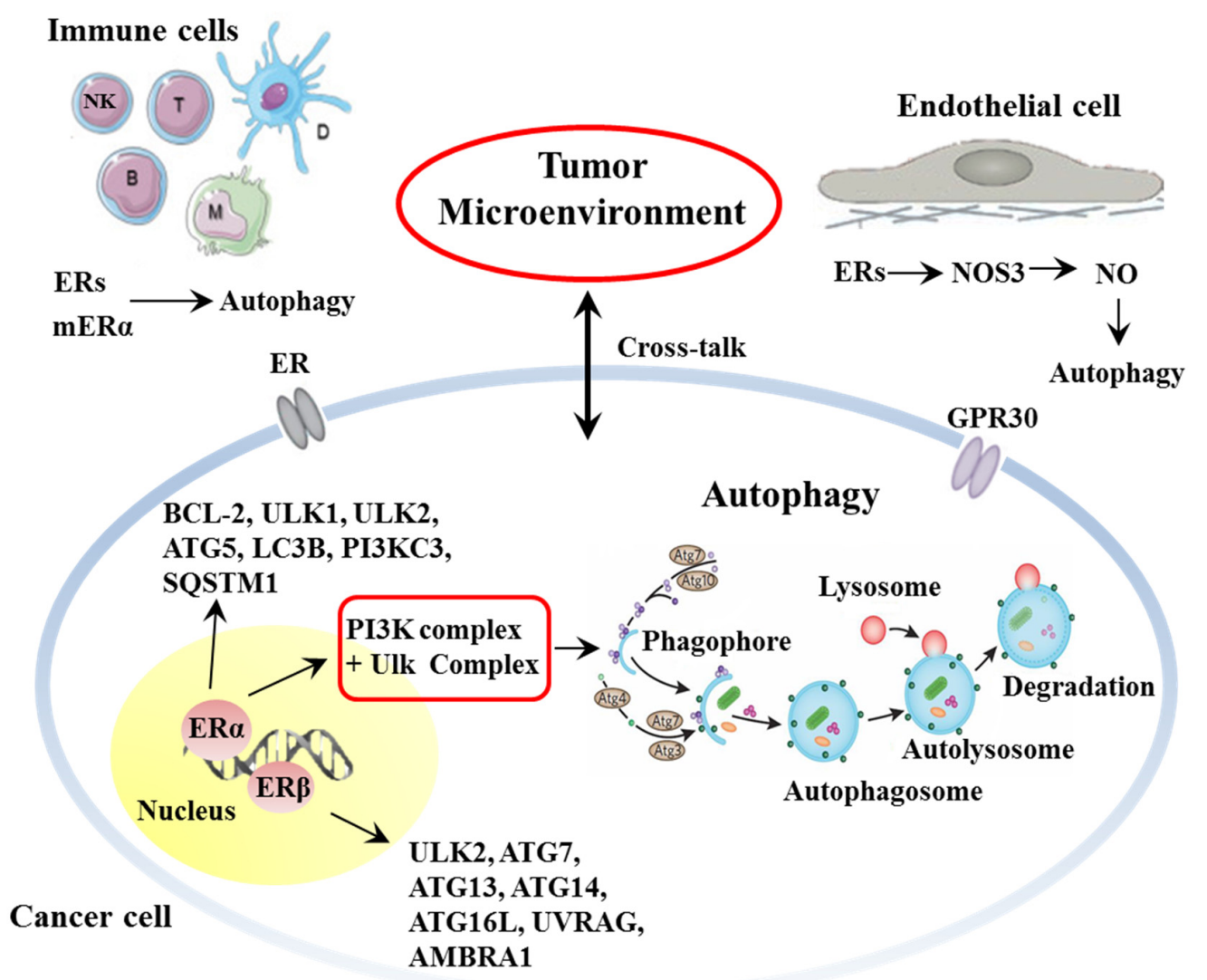

Figure 2. Simplified scheme representing the role of ER in autophagy modulation in cancer and TME.

At the genomic level, ER $\alpha$ has been shown to regulate the transcription of B-cell lymphoma 2 (Bcl-2) and Unc-51-like autophagy activating kinase (ULK)-1, two key molecules 
that determine cell fate $[39,62,63]$. ER $\alpha$ thus seems able to regulate phagophore induction by controlling many autophagy genes in the ULK complex and the phosphatidylinositol 3-kinase (PtdIns3K) complex 1 at the transcriptional level. Bioinformatics analysis confirmed these data, suggesting that both $\operatorname{ER} \alpha$ and $\operatorname{Er} \beta$, at the transcription level, can regulate several autophagy genes [64]. Twelve autophagy genes were observed as regulated by ER $\beta$, including ULK2, ATG7, ATG13, ATG14, ATG16L1, UVRAG, and AMBRA1, and 19 autophagy genes appeared as regulated by ER $\alpha$, such as ULK2, ATG5, LC3B, PIK3C3, and SQSTM1. Moreover, Felzen and co-workers [65] observed that ER $\alpha$ was able to mediate the BAG3-non-canonical autophagy pathway. In another study, Yang and co-workers suggested that $E R \beta$ was involved in the induction of autophagy by the inhibition of the $\mathrm{PI} 3 \mathrm{~K} / \mathrm{AKT} / \mathrm{mTOR}$ pathway and the activation the AMPK pathway [66].

Several further aspects are of great relevance in this context and still need to be investigated in more detail. For instance, the main issues are: (i) the role of mitochondrial ERs that have been detected in many human cell types [67-69]; (ii) the role of estrogen in selective mitochondrial autophagy (mitophagy); (iii) the role of ERs localized in lysosomes [70,71] that could be involved in autophagy induction upon fusion with autophagosomes. Hence, the activity of estrogen and its receptors in regulating cell fate, i.e., survival by autophagy or death by apoptosis, appears to be pivotal.

A final general point to be considered here is represented by the fact that estrogen has been widely demonstrated to play an essential part in the function of TME and autophagy modulation [72]. In endothelial cells, ERs, after binding with their ligands, activate nitric oxide synthase 3 (NOS3) [73], leading to the synthesis of nitric oxide (NO), which can inhibit the expression of mTOR and induce autophagy [74].

As for immune cells, they are known to actively participate in TME formation, maintenance and activity. Autophagy modulates the integrity and function of several immune cell types, such as natural killer (NK) cells, macrophages, dendritic cells, and T- and Blymphocytes [75]. ERs are expressed across multiple immune cell population and modulate their activity [76,77]. Lymphocytes express ERs even at their surface [78], allowing a prompt response to their agonists and, thus, taking part in the modulatory role of TME. In particular, estrogens are involved in regulating neutrophil chemotaxis and proliferation [79] and DCs differentiation [80]. Estrogens, in particular 17- $\beta$ estradiol (E2), have different effects depending on their concentration. At high levels (e.g., pre-ovulatory phase or pregnancy), E2 mainly exerts anti-inflammatory effects, inhibiting the production of pro-inflammatory cytokines, such as TNF- $\alpha$, IL- $1 \beta$ and IL- 6 , and inducing the expression of anti-inflammatory cytokines, such as IL-4, IL-10 and TGF- $\beta$, also favoring Treg function [81]. At lower levels, E2 induces TNF- $\alpha$, IFN- $\gamma$ and IL-1 $\beta$ production and NK cell activity. Moreover, E2, both at high and low concentrations, induces antibody production by $B$ cells. It is worth noting that ER $\alpha$ and $E R \beta$ play opposite roles in immune function, with pro- and anti-inflammatory activity, respectively. Hence, the effects of E2 depend not only on its concentration, but also on the ER subtype expressed by target cells [82,83].

Together, these studies underline the crucial role of the ER/E2 axis in the tumor immune microenvironment [84]. However, the possible immunotherapeutic implications of estrogen targeting in cancer patients is still a matter of study and debate. For example, it has been observed that immunotherapy with immune checkpoint inhibitors (ICI), able to improve the immune response against cancer, is more effective in men than in women. It can be hypothesized that the immune response, constitutively higher in women than in men, cannot be bolstered further $[29,85]$.

\subsection{Estrogen and Cancer}

The activity of estrogen in regulating autophagy appears to be pivotal in the onset and progression of many types of tumors. Below, we will briefly describe four paradigmatic examples of cancers such as colon cancer (CC), lymphoma, melanoma and lung carcinoma (LC), and their strict interplay with estrogen (Table 1). 
Table 1. Examples of Estrogen Receptor $\beta$ mediated effects on autophagy modulation.

\begin{tabular}{|c|c|c|}
\hline Cancer & Effects of ERs on Autophagy & References \\
\hline Colon cancer & $\begin{array}{l}\text { ER } \beta \text { induced autophagy through: } \\
\text { - } \quad \text { mTOR inhibition } \\
\text { - } \quad \text { BNIP3 } \\
\text { - } \quad \text { degradation of KRAS }\end{array}$ & {$[86,87]$} \\
\hline Melanoma & $\begin{array}{l}\text { ER } \beta \text { induced autophagy through: } \\
\text { - } \quad \text { inhibition of the PI3K/Akt pathway }\end{array}$ & [88] \\
\hline $\begin{array}{l}\text { Hodgkin } \\
\text { Lymphoma }\end{array}$ & $\begin{array}{l}\text { ER } \beta \text { induced autophagy through: } \\
\text { - } \quad \text { DRAM2 expression }\end{array}$ & [78] \\
\hline Lung carcinoma & $\begin{array}{l}\text { ER } \beta \text { induced autophagy in NSCLC cells through: } \\
\text { - } \quad \text { binding to FATS } \\
\text { - } \\
\text { hindering the interaction of Bcl-xL and Beclin-1 } \\
\text { (effect mediated by genistein, a selective } \\
\text { agonist of ER } \beta \text { ) }\end{array}$ & {$[89,90]$} \\
\hline
\end{tabular}

\subsubsection{Colon Cancer}

Epidemiological studies reported that men display a higher prevalence of colon cancer. However, ascending colon cancer is more frequent in women, and women aged 18-44 with colon cancer had a better prognosis compared with men of the same age and with post-menopausal women [91]. Upregulated expression of ER $\beta 1$ (the only fully functional isoform of ER $\beta$ ) in colon cancer is associated with an improved survival outcome [92] while the ER $\beta$ expression decreases progressively with the worsening of the stage and grade of colon cancer [93]. The mechanisms underlying this activity are still to be defined in detail. In a recent study, Wei and co-workers [86] demonstrated that ER $\beta$ suppressed proliferation of a colon cancer cell line, i.e., HCT16 cells, without any effect on cancer cell apoptosis. In particular, ER $\beta$ ligation led to G1-S phase arrest in HCT116. The authors demonstrated that ER $\beta$ induced CylinD1 degradation via mTOR-dependent autophagy. Additionally, ER $\beta$ induced autophagic cell death via BNIP3, a member of the Bcl-2 protein family that can modulate the permeability state of the outer mitochondrial membrane. A further aspect to be taken into consideration in colon cancer is the treatment with 4-hydroxytamoxifen, a selective ER modulator widely used in the therapeutic and chemo-preventive treatment of breast cancer, that caused the degradation of KRAS, a protein whose gene appeared often mutated in colon cancer, through autophagy preventing cancer cell growth [87].

The role of ER $\alpha$ in colon cancer cell fate is still poorly studied. It has been observed, however, that this receptor is poorly expressed in colon cancer cells [94].

\subsubsection{Melanoma}

Although melanoma is classically considered a non-hormone-dependent tumor, a growing line of evidence supports a direct correlation between estrogen and melanoma growth and progression [95,96]. Interestingly, the skin is able to produce estrogens [95] since the aromatase, i.e., the enzyme that convers androgens to estrogens, is expressed in melanoma tissues [97]. Melanoma incidence is higher in men than in women but, conversely, women show a better outcome in comparison to men [98]. ER $\alpha$ is the main ER in human skin; however, ER $\beta$ is the predominant ER in melanocytic lesions, and its expression decreases in melanoma progression, supporting its role as a tumor suppressor [99-102]. It is worth noting that the expression levels of ER $\beta$ have been found to be lower in men than in women in both melanoma and healthy tissues, which is in line with sex differences in melanoma patient survival $[103,104]$. Although estradiol (E2, the most important human estrogen) has been observed to be able to hamper melanoma cell proliferation, clinical 
trials failed to demonstrate survival advantages [105]. At variance, in vitro studies with ER $\beta$ agonists have suggested that they could inhibit the proliferation of melanoma cells harboring the NRAS mutation, an important gene of the RAS family [88], indicating that ER $\beta$ might impair melanoma onset through inhibition of the PI3K/Akt pathway. Interestingly, Tamoxifen, a selective estrogen receptor modulator, in combination with the antioxidant curcumin, has been demonstrated to induce autophagy and apoptosis in melanoma cells [89]. However, to date, the role of autophagy in this process should be investigated in more detail.

\subsubsection{Lymphoma}

In general, adult men are slightly more likely to develop lymphoma and have a poorer prognosis and survival than women [30]. Even though the underlying reasons have been scarcely understood, estrogens seem to play a crucial role in these sex differences [90]. Accordingly, the female advantage begins with puberty, increases until menopause, and then declines [30]. In particular, ER $\beta$ activation by selective agonists was found to inhibit the growth of non-Hodgkin lymphoma (NHL, the significantly more frequent form of lymphoma, constituting about $90 \%$ of cases), mainly by reducing cell proliferation [106,107]. Furthermore, ER $\beta$ agonists were also able to prevent lymphoma vascularization and dissemination in mice [106]. In addition, at least in vitro, ER $\beta$-induced damage regulated autophagy modulator 2 (DRAM2)-mediated autophagy has been associated with a reduction in cancer cell proliferation in Hodgkin lymphoma (HL) cells [78].

\subsubsection{Lung Carcinoma}

In the past three decades, lung carcinoma incidence and mortality were significantly decreased in men, whereas they increased among women. In particular, premenopausal women are more frequently diagnosed with advanced stage tumor, have less differentiated tumors, a higher number of distant metastases and worse prognosis than both men and postmenopausal women [108-111]. These different manifestations of LC appear to be at least partially due to estrogen effects. Several points have in fact emerged from the literature. For instance, non-small cell lung cancer (NSCLC) has now been recognized as an ER-positive cancer. Both ER $\alpha$ and $E R \beta$ have been identified in NSCLC $[112,113]$. ER $\beta$ is the predominant type of ER in NSCLC, and ER $\beta$ overexpression correlates with poor prognosis [114,115]. Notably, E2 has been observed to induce NSCLC cell proliferation and tumor growth, mainly from activation of CAMP, MAPK and AKT signaling by nongenomic pathways. Furthermore, E2, which together with high aromatase expression has been reported to be more elevated in tumor compared to healthy lung [112,116,117], induces the expression of c-Myc, Cyclin D, and the inhibitor of differentiation (Id) proteins by genomic pathway, leading to cell cycle progression [118,119]. Moreover, mitochondrial ER $\beta$ has been reported to play anti-apoptotic effects in NSCLC cells [120].

A link between ER $\beta$ and autophagy in LC has been suggested by Qiu and co-workers in a recent study [121]. They observed that fragile-site associated tumor suppressor (FATS), a novel oncogene involved in LC, was significantly downregulated in NSCLC tissues compared with adjacent normal tissues and was associated with the survival of NSCLC patients. The authors demonstrated that the presence of the tumor suppressor FATS in NSCLC cells led to apoptosis by inducing pro-death autophagy. FATS was shown to function as a suppressor of polyamine biosynthesis by inhibiting ornithine decarboxylase (ODC) at the protein and mRNA levels, and this mechanism was dependent on ER $\beta$. In fact, FATS binds to ER $\beta$ and translocates to the cytosol, leading to ODC degradation [121].

The role of ER in autophagy induction in NSCLC has further been supported in a study by Zhang and coworkers [122] that analyzed the effect of genistein, a phytoestrogen that acts as an estrogen receptor agonist, in NSCLC cells. Treatment with genistein significantly enhanced radio-sensitivity of NSCLC cells by increasing apoptosis, which occurs as a result of the inhibition of cytoplasmic Bcl-xL distribution, and autophagy, by hindering the interaction of Bcl-xL and Beclin-1. 


\section{Sex-Specific Epigenetic Control: MicroRNAs and Autophagy}

MicroRNAs are potent epigenetic regulators of gene expression, capable of posttranscriptional gene control. They, acting on the stability or translation of mRNA, modulate a number of targeted proteins in the cell. Experimental evidence has clearly demonstrated their impressive role in cancer development and progression. More than $2000 \mathrm{miRs}$ were discovered, with tumor suppressor or oncogenic roles, thus contributing to various stages of cancer formation and progression, and eventually favoring resistance to treatment [123]. A great number of works have described miR biogenesis and transcriptional regulation and we refer to them for exhaustive explanation [124,125]. miRs were shown to modulate levels of several key proteins of the autophagy pathway, from the upstream signaling of vesicle nucleation to later stages of autolysosome degradation. Autocrine and paracrine signals, respectively representing pro- and anti-oncogenic mechanisms, can be sustained by miRs, either bound with some specific proteins or loaded and released by extracellular vesicles, favoring communication among tumor cells, and between tumor and stroma cells as well as tumors and distant compartments [126]. Sometimes, as stated above, this cross talk is complicated by hormonal regulation, mainly based on estrogen, that might influence autophagic or apoptotic responses. Although miR action favors cancer cell adaptation to host responses against tumor, including immune and pharmacological responses, some miRs are able to modulate the autophagic pathway to achieve the desired final effect of apoptotic program activation, finally reducing the tumor burden. This effect is essential for silenced tumor suppressor miRs that, when re-expressed, can act in association with anticancer drugs, favoring therapeutic response (Table 2). Finally, as noted above, the $X$ chromosome contains a high number of miRs (about $10 \%$ of the total) and the incomplete inactivation of one of the two X chromosomes in female cells could lead to the sexual dimorphism observed in the expression of some X-linked miRs [43-45]. Only four miRs have been so far identified on the Y chromosome [42].

Table 2. MicroRNAs involved in autophagy/apoptosis regulation.

\begin{tabular}{|c|c|c|c|c|}
\hline Cancer & microRNAs & Targeted Proteins & Effect on Tumor Cells & References \\
\hline \multirow{3}{*}{ Colon Cancer } & miR-210 & Bcl-2 & Induces autophagy and radioresistance & [127] \\
\hline & miR-22 & BTG1 & Inhibits autophagy and promotes apoptosis & [128] \\
\hline & miR-27a & Calreticulin & Inhibits autophagy and apoptosis & [129] \\
\hline \multirow{3}{*}{ Melanoma } & miR-23a & ATG12 & Inhibits autophagy and reduces invasiveness & [130] \\
\hline & miR-26a & HMGB1 & Inhibits autophagy and induces apoptosis & [131] \\
\hline & $\operatorname{miR}-142-3 p$ & Rheb & Induces autophagy and apoptosis & [132] \\
\hline \multirow{2}{*}{ Hodgkin Lymphoma } & miR-342-3p & MAP1LC3B, DNMT1 & Inhibits autophagy and induces cell death & [133] \\
\hline & miR-449a & ATG4B & Inhibits autophagy and induces apoptosis & [134] \\
\hline \multirow{4}{*}{ Lung Carcinoma } & miR-153-3p & ATG5 & Inhibits autophagy and induces apoptosis & [135] \\
\hline & miR-106a & ULK1 & Inhibits autophagy and induces apoptosis & [136] \\
\hline & $\operatorname{miR}-23 a$ & PTEN & Induces autophagy and inhibits apoptosis & [137] \\
\hline & miR-384 & COL10A1 & Induces autophagy and apoptosis & [138] \\
\hline
\end{tabular}

Bcl-2, B-cell lymphoma 2; BTG1, B-cell Translocation Gene 1; ATG12, Autophagy-related 12; HMGB1, High mobility group box 1; Rheb, Ras homolog enriched in brain; MAP1LC3B, Microtubule-associated protein 1A/1B light chain 3B; DNMT1, DNA Methyltransferase 1; ATG4B, Autophagy-associated 4B; ATG5, Autophagy-related 5; ULK1, Unc-51-like autophagy activating kinase 1; PTEN, Phosphatase and tensin homolog; COL10A1, Collagen $\alpha-1(\mathrm{X})$ chain.

\subsection{Colon Cancer}

Colon cancer can, in part, be recognized as a complication of long-term colon inflammatory diseases, such as Crohn's disease (CD) and ulcerative colitis (UC), primarily due to an abnormal immune response in which dysfunction of autophagy has been considered an important contributing factor [139]. In this microenvironment, some miRs are inhibitors of autophagy by regulating different ATG proteins, eventually influencing the innate immune response. Sex hormones might participate in miR-specific regulation, in turn contributing to the regulation of autophagy responses. For instance, miR-142-3p affects the immune microenvironment in CD by direct targeting of IL-8 mRNA expression and inhibition of 
inflammatory bowel disease protein 1 (IBD1)-dependent autophagy [140]. However, in the tumor context, the same miR was down modulated by ER $\beta$ expression in colon cancer cell lines, through an estrogenic binding site upstream of the miR-142-3p locus [141]. Evolution of $C D$ in $C C$ and its progression are characterized by increased hypoxic microenvironment advantaging glycolysis in parallel with increased autophagy activation to avoid tumor cell death. In this condition, the efficacy of therapeutic actions is particularly complicated, possibly favoring tumor cell metastatization.

The autophagic flux in human colon cancer cell lines grown in hypoxia is regulated by HIF-1 $\alpha$ expression. HIF- $\alpha$, in turn, positively regulates miR-210, which, by limiting the expression of Bcl-2, induces cell autophagy, eventually contributing to radio resistance [127].

Furthermore, some miRs control, at different levels, the autophagy activation, favoring drug sensitivity of CC cells. MiR-22, which inhibits estrogen signaling by direct targeting of ER $\alpha$ mRNA, can increase cell sensitivity to 5-fluorouracil (5FU) inhibiting autophagy by regulation of the B-cell translocation gene 1 (BTG1), a regulator of cell growth and differentiation [128,142].

It is now clear that chemotherapy efficacy is also associated with a good immune response, whereas autophagy determines immune evasion. Indeed, both apoptotic- and autophagy-dependent cell deaths are potent activators of the adaptive immune response through the release of the Damage-Associated Molecular Patterns (DAMPs). DAMPs are recognized by receptors of dendritic cells and finally favor the development of productive microenvironments with expression of cytokines that are capable of promoting immune response and, more importantly, of activating the immune cell mediated apoptotic program [143]. The opposite action of miR-27a, induced by drug treatments that inhibits DAMPs' release eventually supporting autophagy activation and resistance, should also be considered. In a favorable microenvironment, the low expression of miR-27a, which indirectly regulates ER $\alpha$ expression and hormone responsiveness [144], is associated with a good prognosis in CC, which responds with immunogenic cell death to chemotherapy [129].

A final point to be considered is that CC TME is characterized by a massive presence of cancer-associated fibroblasts (CAFs) that, interacting with tumor cells, secrete extracellular matrix components and growth factors that regulate immune response. It was evidenced that CAFs were capable of negatively modulating the expression of diverse autophagyrelated proteins in tumor cells through miR-31. Importantly, this interaction positively affected the sensitivity of CC cells to radiation therapy [13].

\subsection{Melanoma}

Autophagy activation is important in the protection of normal epidermis from ultraviolet irradiation. In these stress conditions, autophagy is activated to avoid the detrimental effect of photo-aging, a phenomenon that is associated with diverse pathologies, including skin cancer. Abnormality in autophagy was related to the expression of miR-23a, which caused premature senescence of epidermal fibroblasts. This event was avoided by antagomiR-mediated inactivation of miR-23a, with the consequent stimulation of ultraviolet-dependent autophagy protecting human fibroblasts from premature senescence. The limiting factor in the rescue of fibroblast senescence was the AMBRA1 protein, identified as an miR-23a target [145]. The same miR works as tumor suppressor in melanoma, being down-modulated in serum and tissues of patients with metastatic melanoma, which is, in turn, associated with metastasis formation. When re-expressed in A2058 and A375 melanoma cell lines, invasion capability was strongly reduced by the miR-23a-dependent ATG12 targeting and relative autophagy inhibition [130].

One prerogative of the tumor setting is the high grade of adaptability of tumor cells to extreme microenvironments, eventually becoming capable of inducing the autophagy process through miR regulation [146-149]. An example of this is miR-26a, whose levels drop in melanoma cells treated with dabrafenib (a drug targeting a mutated version of the gene BRAF (V600E)). Beyond pharmacological treatment, the effect on autophagy activation by miR-26a silencing was a consequence of the deficiency in the endothelial recovery, 
associated with the absence of miR-26a dependent differentiation of mesenchymal stem cells in functional endothelial cells. This deficiency, reducing tumor blood flow, favored the Warburg effect in the TME [150]. Indeed, miR-26a re-expression sensitized melanoma cell lines to dabrafenib, targeting the high mobility group box 1 (HMGB1)-dependent autophagy, and finally, engaging the apoptosis program [131].

Different miRs induce autophagy by silencing the expression of proteins associated with the mTOR signaling pathway. Licochalcone A is a phytoestrogen of the flavonoid family (LCA), with an antioxidant protectant role, that has been shown to exert anticancer activity by inducing autophagy and apoptosis. In A375 and B16 melanoma cell lines, this effect was associated with up-modulation of miR-142-3p and decreased expression of its target, the Ras homolog enriched in brain (Rheb) protein, with consequent suppression of mTOR signaling activation [132]. These data seem to suggest a reappraisal of phytoestrogens in the clinical control of melanoma.

More generally, the recent elegant review by Dika and colleagues [151] describes in some detail the influence of ERs on melanoma, also evaluating sex disparity for this form of cancer, whose incidence continues to increase globally. In particular, these authors claim that there is a direct correlation between estrogens and the female survival advantage, which seems to be abrogated in the postmenopausal period, during which estrogen levels decrease. Either a network involving ERs and miRs, characterized by a direct effect of estrogen on miR expression or, at variance, revealing a direct regulatory effect of miRs on ER expression, seems to take place. For example, estrogen signaling triggered by ER $\alpha$ appears to inhibit the levels of miR-21, miR-26a, miR-140, miR-181b and miR-206, whereas it upregulates miR-190a, miR-191, miR-203 and miR-425. In addition, ER $\beta$ signaling participates in these pathways by downregulating miR-17, miR-30a, miR-200a and miR$200 \mathrm{~b}$, and inducing the overexpression of miR-23b, miR-24- 1 and miR-27b. These data appear to underscore the complex anatomy of estrogen/TME crosstalk as a determinant of the melanocyte/melanoma control pathway.

\subsection{Lymphoma}

Currently, miR involvement in the regulation of autophagy in lymphoma has barely been investigated. Some miRs have been shown to have a tumor suppressor role and their expression was commonly silenced by epigenetic regulation, indicating a pathogenetic mechanism for lymphoma development. In B-cell lymphoma, miR-342 is associated with $\mathrm{ER} \alpha$ expression. It is localized on chromosome 14 in the third intron of its host gene Enah/Vasp-like (EVL), a regulator of actin cytoskeleton remodeling, which is essential for cell migration ability. In primary samples of B cell lymphoma, miR-342 was found to be silenced by hyper methylation of the promoter region of the EVL gene, and 5AzadC treatment resulted in re-expression of miR-342-3p and EVL protein. Furthermore, transfection of synthetic miR-342-3p reduced cell proliferation and inhibited autophagy in SU-DHL-16 cells, eventually increasing cell death. The microtubule-associated proteins 1A/1B light chain 3B (MAP1LC3B), a precursor of the autophagy functional marker light chain 3 (LC3)-II, and DNA methyltransferase-1, were validated as targets of miR-342-3p. The negative regulation of the DNA methyltransferase- 1 by miR-342 induced DNA hypo methylation and reduced lymphoma malignancy $[133,152,153]$.

T cell lymphoma is a non-Hodgkin's lymphoma originating from $\mathrm{T}$ cells characterized by high heterogeneity and malignancy. The absence of an effective cure for this pathology indicates that novel strategies of treatment must be developed. Therefore, it has been proposed that targeting autophagy might reconstitute sensitivity to doxorubicin in this disease. Indeed, in this lymphoma, miR-449a is frequently silenced. This miR acts as a tumor suppressor in human glioblastoma and hepatocellular carcinoma, and it suppresses anti-estrogenic treatment resistance in human breast cancer cells [154]. Expression of miR-449a attenuated autophagy and induced apoptosis in T cell lymphoma cells. Direct targeting of ATG4B mRNA induced this effect. In vivo experiments also demonstrated growth inhibition of $\mathrm{T}$ cell lymphoma xenograft tumors in nude mice, which was associated 
with activation of the pro-apoptotic program, as indicated by increased cleaved Caspase-3 and PARP [134].

\subsection{Lung Carcinoma}

Among other factors, the role of miRs and their altered and deregulated levels appear to be critical in lung cancer. If intercepted in time, by specific serum assays, they could represent a fundamental tool for increased diagnostic/therapeutic opportunities, especially in drug resistant microenvironments that are responsible for the untreatable metastasizing events. NSCLCs that are resistant to gefitinib, a selective EGFR tyrosine kinase inhibitor, are characterized by low expression of miR-153-3p, which is inversely correlated with the autophagy marker LC3B. ATG5 is a direct target of miR-153-3p, and in gefitinib-resistant NSCLC, the ATG5 level was high, in parallel with autophagy activity. Accordingly, because of miR-153-3p restored expression, in lung cancer cell lines, autophagy can be reduced and apoptotic cell death strengthened [135]. Of note, evidence has been reported of a functional interaction between the ER and the EGFR pathways in NSCLC. In particular, combined targeting of the estrogen receptor and the epidermal growth factor receptor in NSCLC has demonstrated the enhancement of their antiproliferative effects [155]. This could open new scenarios in the understanding of either possible alternative pathogenetic mechanisms or therapeutic options in men and women. In fact, some miRs can modify the therapeutic performance of specific drugs, removing the protective autophagy in lung cancer cell lines and inducing apoptotic programs. In this context, the X-linked miR-106a was indicated in ULK1 targeting, being essentially down-modulated after treatments with tyrosine kinase inhibitors and other chemotherapeutic agents. MiR-106a silencing, beyond blocking the apoptotic program, increased the level of ULK1, favoring a protective autophagy [136]. In addition, it was proposed that the ER $\alpha$ transcriptional programs could involve miR-106a activity and function [156].

Cisplatin resistance is the major problem in the treatment of advanced lung cancer. The naturally occurring triterpenoid quinone, a compound with antiestrogenic activity named pristimerin [157], induced enhanced chemosensitivity to cisplatin treatment. The mechanism underlying this increased sensitivity was investigated in A549 and NCIH446 lung cancer cell lines and in in vivo experiments. The authors found that pristimerin, possibly thanks to its antiestrogenic activity, was capable of synergizing with cisplatin to inhibit the miR-23a/Akt/glycogen synthase kinase $3 \beta$ signaling pathway, thus suppressing autophagy. These inhibitory events were associated with increased tumor cell death by apoptosis [137].

Sex dimorphism in the cell response to drugs has been suggested to be, at least in part, due to female sex-biased expression of miRs, e.g., the $X$ chromosome-encoded miRs potentially escaping $X$ chromosome inactivation $(X C I)$. A few $X$-linked miRs have been analyzed in some detail but, unfortunately, their activity is still far from being well elucidated. Among them, the X-linked miR-384 was found to be down-regulated in lung cancer. Indeed, when expressed in lung cancer cell lines and implanted in nude rats, miR-384 favored autophagy and apoptosis by targeting the TME Collagen $\alpha-1(\mathrm{X})$ chain (COL10A1), while it inhibited proliferation [138]. This suggests a further role of the $\mathrm{TME} / \mathrm{miR} /$ cancer interplay.

Hence, as a rule, a great deal of work still appears to be necessary in order to elucidate the possible redundant expression of X-linked miRs, mainly those with tumor suppressor roles that are commonly silenced by epigenetic regulation. These miRs, if maintained in an activated state, might partially explain the differences in the pathogenetic mechanisms of cancer development between the two sexes.

\section{TME-Cancer Cells Crosstalk as Possible Target for Cancer Growth Control}

As described above, autophagy is an essential process contributing to cell cytoprotection and homeostasis. It is strictly related to the metabolic supply by intracellular milieu as well as by extracellular constituents, e.g., those composing the TME. Several results 
obtained both in vitro and in in vivo mouse models of cancers showed that autophagy could impair the growth of benign lesions, but could favor that of malignant ones [158]. Indeed, tumor initiation is impaired by the autophagic actions, and Beclin1 was reported as a tumor suppressor in breast, ovarian, and prostate cancers. In addition, autophagy can reduce tumor metastases by down-regulating some transcription factors involved in the EMT transition, such as Snail and Slug, in turn favoring E-cadherin cell adhesion molecule expression [159]. Although several data suggested autophagy as a possible therapeutic target, the double action exerted by this process in cancer made it difficult to select key factors and biological processes to aim at, and the quantity of apparently controversial data indicates the relevance of considering the context-associated roles of autophagy [160]. Generally, in cancer studies, the induction of autophagy could represent a useful action leading to the blocking of cell cycle progression and, in turn, of cell proliferation. However, as reported above, this could lead to the so-called dormant cancer cells giving rise to relapsing disease.

In the last decade, the identification of novel therapeutic drugs led to significant results for several tumor types, thus improving patients' survival. Nonetheless, drug resistance still represents a major challenge, which reinforces the need to further dissect the molecular abnormalities underlying cancer progression. Indeed, a better comprehension of the process is required to solve the debate around inhibiting or inducing autophagy. Actually, the complexity of this functional pathway was shown by many different studies. In vivo studies in mouse models supported the possible therapeutic value of inducing autophagy, as the loss of one Beclin1 allele favored the development of tumors. However, this result was not confirmed in cancer patients, where BECN1 did not seem to represent a key player [161], and autophagy induced by antitumorigenic drugs demonstrated protective results for tumor cells [162].

According to some negative results associated with induced autophagy, the majority of the studies are now focused on its inhibition. At present, many different drugs have been developed for experimental research, but they still lack confirmed specificity and suitability in vivo. The main aim of these studies was precisely the idea of hindering the "feeding" of cancer cells via TME, an important source of metabolites and nutrients [163].

Looking at the US National Library of Medicine (search dated May 2021), located at ClinicalTrials.gov, using the search terms Cancer and Autophagy, we found 84 studies, most of them based on hydroxychloroquine alone or in combination. Eleven studies are terminated, with their results available, but the number of recruited subjects was generally low and insufficient data were collected. In addition, due to lack of therapeutic improvement with respect to controls, several studies were interrupted ahead of schedule. However, it cannot be ruled out that the antitumor effects shown by chloroquine and its derivatives are not directly linked to the induction of autophagy on cancer cells. In fact, very interestingly, some in vitro and in vivo studies demonstrated that the tumor cell sensitivity to quinacrine [164] or hydroxychloroquine [165], two chloroquine derivatives, were strongly dependent on TME.

Among the autophagy-related proteins, we should also consider mTOR, the mechanistic target of rapamycin that has been shown to represent a key target, specifically its inhibition associated with autophagy induction. Rapamycin and its derivatives, such as everolimus and sirolimus, have been demonstrated to inhibit proliferation in several different human tumors [166]. Recent evidence also showed the higher effectiveness of combination treatment of mTOR inhibitors with hydroxychloroquine [167]. Although everolimus appears capable of affecting the integrity and function of some lymphocyte subsets, its effects on immune cell components of TME are still a matter of debate [168]. In fact, with the growing relevance of immunotherapy in the fight against cancer, the interplay between autophagy and immune responses, either in general or associated with TME, appears to be of great interest. The induction of both innate and adaptive immune responses might reinforce or reduce the therapeutic effects of immunotherapies [75]. Whenever 
completely clarified, all these connections might provide some novel therapeutic targets that will possibly be translatable into effective therapeutic strategies [169].

\title{
5. Conclusions
}

As both the microenvironment and sex, e.g., hormones and sex chromosomes, as well as autophagy inhibition or bolstering appear to affect the responsiveness of tumor cells to therapy, the development of novel experimental models appears to be an indispensable tool to develop increasingly targeted and personalized therapies. These models should recreate the physiological and mechanical cues typical of cancer microenvironment, recapitulating the relationship between tumor cells and TME and possibly reproducing sexual dimorphism [39]. Recent advances in three-dimensional (3D) modeling, also using chips and microfluidic devices [170,171], provide us with the opportunity of studying the biology of TME. Understanding the cellular and molecular mechanisms that govern the complex interactions between tumor cells and microenvironments could contribute to the progress of therapeutic strategies that encompass the biological complexity of a tumor by reducing the gap between translational research and clinical practice.

Since autophagy has variable effects on tumor cells, depending on the context and stage, the role of TME in providing further survival options to cancer cells could be pivotal. However, the relevance of the microenvironment is due to its heterogeneous composition where signals, e.g., hormones, immune-inflammatory cells, recyclable materials, and ECM proteins, are paired with the origin of cancer cells not only by a histotypical point of view or by tumor staging, but also by a novel and fascinating point of view: the "sex" of the cell. Based on the previously published observations on the disparity of cancers between women and men in terms of incidence, progression and response to therapy [19], this field could represent a novel challenge and a first key step for the development of precision medicine.

Systematic research on sex differences in cancer biology is needed to evaluate sexspecific dosages of anticancer drugs, especially for those that show significant pharmacokinetic differences in the two sexes, thereby improving the efficacy/toxicity ratio. In addition, for tumors or tumor subtypes with significant gender differences in incidence and outcome, sex-specific therapeutic approaches should already be considered. A better understanding of the molecular-pathogenetic mechanisms underlying these differences could guarantee effective improvement in a personalized and tailored approach that is of great relevance in the fight against cancer.

Author Contributions: P.M. and G.M. wrote the work, particularly the paragraphs dealing with autophagy and microRNA; M.T.P. and G.P. contributed to figure drawing, bibliographic research, and manuscript editing and revisions; E.O. and A.C. designed the work, particularly contributing to the paragraphs dealing with hormones, and to the description of different cancers in a sex-specific perspective, and supervised manuscript drafting; W.M. supervised manuscript drafting, revised the work and coordinated the different tasks of the manuscript drafting process. All authors have read and agreed to the published version of the manuscript.

Funding: This research received no external funding.

Data Availability Statement: The data presented in this study is available within the article.

Conflicts of Interest: The authors declare no conflict of interest.

\author{
Abbreviations \\ 5FU 5-fluorouracil \\ AKT protein Kinase B \\ AMPK adenosine monophosphate-activated protein kinase \\ ATG autophagy gene \\ Bcl-2 B-cell lymphoma 2 \\ Bcl-xL B-cell lymphoma-extra large
}




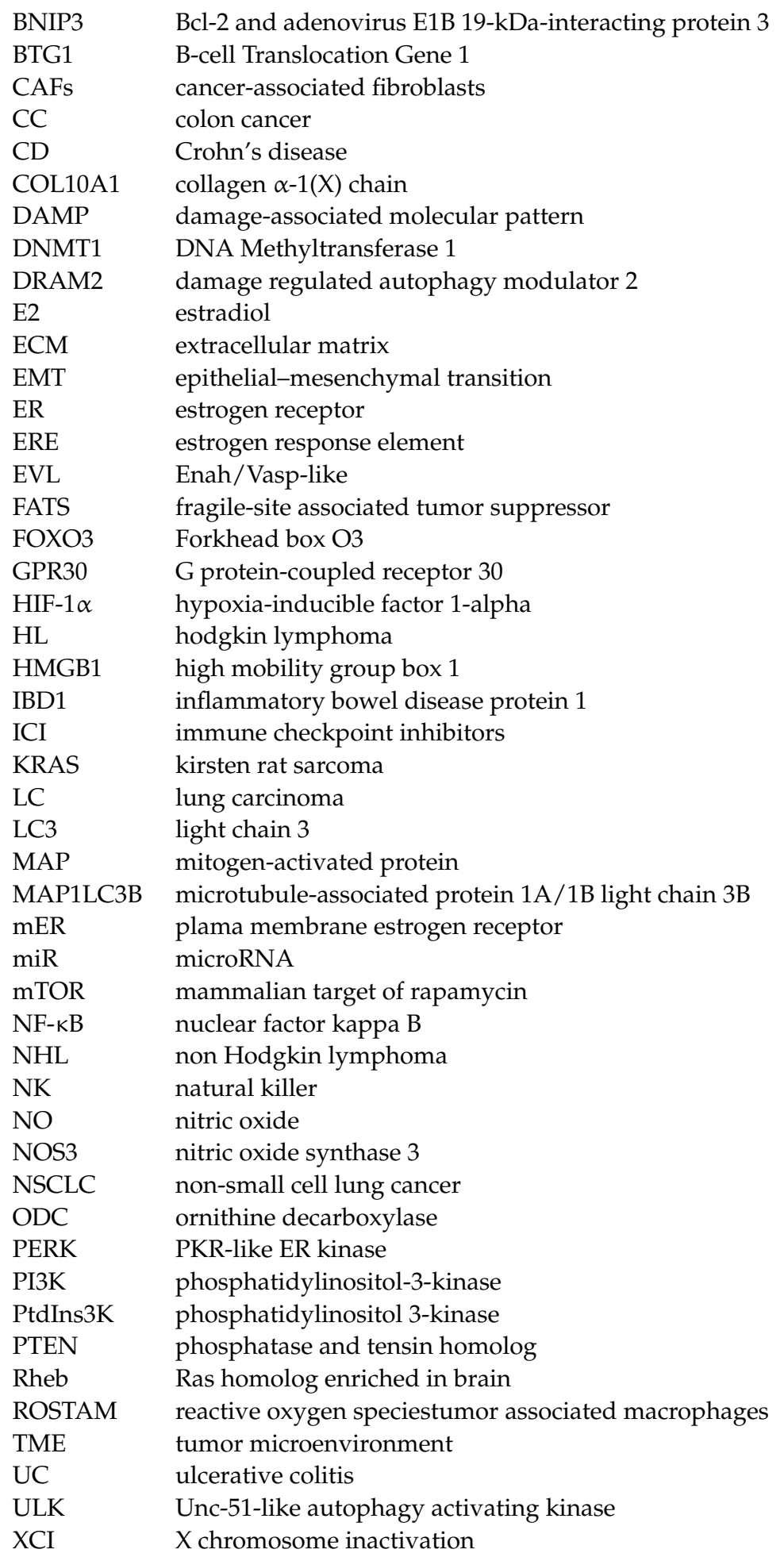

\section{References}

1. Fouad, Y.A.; Aanei, C. Revisiting the hallmarks of cancer. Am. J. Cancer Res. 2017, 7, 1016-1036.

2. Metcalf, K.J.; Alazzeh, A.; Werb, Z.; Weaver, V.M. Leveraging microenvironmental synthetic lethalities to treat cancer. J. Clin. Investig. 2021, 131, e143765. [CrossRef] [PubMed]

3. Bacac, M.; Stamenkovic, I. Metastatic cancer cell. Annu. Rev. Pathol. 2008, 3, 221-247. [CrossRef] [PubMed]

4. Hanahan, D.; Weinberg, R.A. Hallmarks of cancer: The next generation. Cell 2011, 144, 646-674. [CrossRef]

5. Malorni, W.; Matarrese, P.; Tinari, A.; Farrace, M.G.; Piacentini, M. Xeno-cannibalism: A survival "escamotage". Autophagy 2007, 3, 75-77. [CrossRef] 
6. Matarrese, P.; Ciarlo, L.; Tinari, A.; Piacentini, M.; Malorni, W. Xeno-cannibalism as an exacerbation of self-cannibalism: A possible fruitful survival strategy for cancer cells. Curr. Pharm. Des. 2008, 14, 245-252.

7. Wilde, L.; Roche, M.; Domingo-Vidal, M.; Tanson, K.; Philp, N.; Curry, J.; Martinez-Outschoorn, U. Metabolic coupling and the Reverse Warburg Effect in cancer: Implications for novel biomarker and anticancer agent development. Semin. Oncol. 2017, 44, 198-203. [CrossRef]

8. Kreuzaler, P.; Panina, Y.; Segal, J.; Yuneva, M. Adapt and conquer: Metabolic flexibility in cancer growth, invasion and evasion. Mol. Metab. 2020, 33, 83-101. [CrossRef]

9. Klionsky, D.J.; Abdel-Aziz, A.K.; Abdelfatah, S.; Abdellatif, M.; Abdoli, A.; Abel, S.; Abeliovich, H.; Abildgaard, M.H.; Abudu, Y.P.; Acevedo-Arozena, A.; et al. Guidelines for the use and interpretation of assays for monitoring autophagy (4th edition) (1). Autophagy 2021, 17, 1-382. [CrossRef]

10. Lorin, S.; Hamai, A.; Mehrpour, M.; Codogno, P. Autophagy regulation and its role in cancer. Semin. Cancer Biol. 2013, 23, 361-379. [CrossRef]

11. Galluzzi, L.; Pietrocola, F.; Bravo-San Pedro, J.M.; Amaravadi, R.K.; Baehrecke, E.H.; Cecconi, F.; Codogno, P.; Debnath, J.; Gewirtz, D.A.; Karantza, V.; et al. Autophagy in malignant transformation and cancer progression. EMBO J. 2015, 34, 856-880. [CrossRef]

12. Akkoc, Y.; Peker, N.; Akcay, A.; Gozuacik, D. Autophagy and Cancer Dormancy. Front. Oncol. 2021, 11, 627023. [CrossRef]

13. Yang, X.; Xu, X.; Zhu, J.; Zhang, S.; Wu, Y.; Zhao, K.; Xing, C.; Cao, J.; Zhu, H.; Li, M.; et al. miR-31 affects colorectal cancer cells by inhibiting autophagy in cancer-associated fibroblasts. Oncotarget 2016, 7, 79617-79628. [CrossRef]

14. Taniguchi, K.; Karin, M. NF-kappaB, inflammation, immunity and cancer: Coming of age. Nat. Rev. Immunol 2018, 18, 309-324. [CrossRef]

15. Vara-Perez, M.; Felipe-Abrio, B.; Agostinis, P. Mitophagy in Cancer: A Tale of Adaptation. Cells 2019, 8, 493. [CrossRef]

16. Bernardini, J.P.; Lazarou, M.; Dewson, G. Parkin and mitophagy in cancer. Oncogene 2017, 36, 1315-1327. [CrossRef]

17. Poillet-Perez, L.; Xie, X.; Zhan, L.; Yang, Y.; Sharp, D.W.; Hu, Z.S.; Su, X.; Maganti, A.; Jiang, C.; Lu, W.; et al. Autophagy maintains tumour growth through circulating arginine. Nature 2018, 563, 569-573. [CrossRef]

18. Abdrakhmanov, A.; Kulikov, A.V.; Luchkina, E.A.; Zhivotovsky, B.; Gogvadze, V. Involvementofmitophagy in cisplatin-induced cell death regulation. Biol. Chem. 2019, 400, 161-170. [CrossRef]

19. Kimmelman, A.C.; White, E. Autophagy and Tumor Metabolism. Cell Metab. 2017, 25, 1037-1043. [CrossRef]

20. Rohani, N.; Hao, L.; Alexis, M.S.; Joughin, B.A.; Krismer, K.; Moufarrej, M.N.; Soltis, A.R.; Lauffenburger, D.A.; Yaffe, M.B.; Burge, C.B.; et al. Acidification of Tumor at Stromal Boundaries Drives Transcriptome Alterations Associated with Aggressive Phenotypes. Cancer Res. 2019, 79, 1952-1966. [CrossRef]

21. Robey, I.F.; Baggett, B.K.; Kirkpatrick, N.D.; Roe, D.J.; Dosescu, J.; Sloane, B.F.; Hashim, A.I.; Morse, D.L.; Raghunand, N.; Gatenby, R.A.; et al. Bicarbonate increases tumor $\mathrm{pH}$ and inhibits spontaneous metastases. Cancer Res. 2009, 69, 2260-2268. [CrossRef]

22. Potzl, J.; Roser, D.; Bankel, L.; Homberg, N.; Geishauser, A.; Brenner, C.D.; Weigand, M.; Rocken, M.; Mocikat, R. Reversal of tumor acidosis by systemic buffering reactivates NK cells to express IFN-gamma and induces NK cell-dependent lymphoma control without other immunotherapies. Int. J. Cancer 2017, 140, 2125-2133. [CrossRef]

23. Ghafouri-Fard, S.; Shoorei, H.; Mohaqiq, M.; Majidpoor, J.; Moosavi, M.A.; Taheri, M. Exploring the role of non-coding RNAs in autophagy. Autophagy 2021, 1-22. [CrossRef]

24. Raue, R.; Frank, A.C.; Syed, S.N.; Brune, B. Therapeutic Targeting of MicroRNAs in the Tumor Microenvironment. Int. J. Mol. Sci. 2021, 22, 2210. [CrossRef]

25. Clocchiatti, A.; Cora, E.; Zhang, Y.; Dotto, G.P. Sexual dimorphism in cancer. Nat. Rev. Cancer 2016, 16, 330-339. [CrossRef]

26. Haupt, S.; Caramia, F.; Klein, S.L.; Rubin, J.B.; Haupt, Y. Sex disparities matter in cancer development and therapy. Nat. Rev. Cancer 2021, 21, 393-407. [CrossRef]

27. Costa, A.R.; Lanca de Oliveira, M.; Cruz, I.; Goncalves, I.; Cascalheira, J.F.; Santos, C.R.A. The Sex Bias of Cancer. Trends Endocrinol. Metab. 2020, 31, 785-799. [CrossRef]

28. Gabriele, L.; Buoncervello, M.; Ascione, B.; Bellenghi, M.; Matarrese, P.; Care, A. The gender perspective in cancer research and therapy: Novel insights and on-going hypotheses. Ann. Ist. Super. Sanita 2016, 52, 213-222.

29. Irelli, A.; Sirufo, M.M.; D’Ugo, C.; Ginaldi, L.; De Martinis, M. Sex and Gender Influences on Cancer Immunotherapy Response. Biomedicines 2020, 8, 232. [CrossRef]

30. Wagner, A.D.; Oertelt-Prigione, S.; Adjei, A.; Buclin, T.; Cristina, V.; Csajka, C.; Coukos, G.; Dafni, U.; Dotto, G.P.; Ducreux, M.; et al. Gender medicine and oncology: Report and consensus of an ESMO workshop. Ann. Oncol. 2019, 30, 1914-1924. [CrossRef]

31. Li, C.H.; Haider, S.; Shiah, Y.J.; Thai, K.; Boutros, P.C. Sex Differences in Cancer Driver Genes and Biomarkers. Cancer Res. 2018, 78, 5527-5537. [CrossRef]

32. Muscogiuri, G.; Altieri, B.; Albertelli, M.; Dotto, A.; Modica, R.; Barrea, L.; Fanciulli, G.; Feola, T.; Baldelli, R.; Ruggeri, R.M.; et al. Epidemiology of pancreatic neuroendocrine neoplasms: A gender perspective. Endocrine 2020, 69, 441-450. [CrossRef]

33. Park, J.; Shin, H.; Song, H.; Lim, H.J. Autophagic regulation in steroid hormone-responsive systems. Steroids 2016, 115, 177-181. [CrossRef]

34. Du, L.; Hickey, R.W.; Bayir, H.; Watkins, S.C.; Tyurin, V.A.; Guo, F.; Kochanek, P.M.; Jenkins, L.W.; Ren, J.; Gibson, G.; et al. Starving neurons show sex difference in autophagy. J. Biol. Chem. 2009, 284, 2383-2396. [CrossRef]

35. Lista, P.; Straface, E.; Brunelleschi, S.; Franconi, F.; Malorni, W. On the role of autophagy in human diseases: A gender perspective. J. Cell Mol. Med. 2011, 15, 1443-1457. [CrossRef] 
36. Maselli, A.; Matarrese, P.; Straface, E.; Canu, S.; Franconi, F.; Malorni, W. Cell sex: A new look at cell fate studies. FASEB J. 2009, 23, 978-984. [CrossRef]

37. Muralimanoharan, S.; Li, C.; Nakayasu, E.S.; Casey, C.P.; Metz, T.O.; Nathanielsz, P.W.; Maloyan, A. Sexual dimorphism in the fetal cardiac response to maternal nutrient restriction. J. Mol. Cell Cardiol. 2017, 108, 181-193. [CrossRef]

38. Straface, E.; Vona, R.; Gambardella, L.; Ascione, B.; Marino, M.; Bulzomi, P.; Canu, S.; Coinu, R.; Rosano, G.; Malorni, W.; et al. Cell sex determines anoikis resistance in vascular smooth muscle cells. FEBS Lett. 2009, 583, 3448-3454. [CrossRef]

39. Shang, D.; Wang, L.; Klionsky, D.J.; Cheng, H.; Zhou, R. Sex differences in autophagy-mediated diseases: Toward precision medicine. Autophagy 2020, 17, 1065-1076. [CrossRef]

40. Cui, C.; Yang, W.; Shi, J.; Zhou, Y.; Yang, J.; Cui, Q. Identification and Analysis of Human Sex-biased MicroRNAs. Genom. Proteom. Bioinform. 2018, 16, 200-211. [CrossRef]

41. Kukurba, K.R.; Parsana, P.; Balliu, B.; Smith, K.S.; Zappala, Z.; Knowles, D.A.; Fave, M.J.; Davis, J.R.; Li, X.; Zhu, X.; et al. Impact of the X Chromosome and sex on regulatory variation. Genome Res. 2016, 26, 768-777. [CrossRef]

42. Pinheiro, I.; Dejager, L.; Libert, C. X-chromosome-located microRNAs in immunity: Might they explain male/female differences? The $\mathrm{X}$ chromosome-genomic context may affect $\mathrm{X}$-located miRNAs and downstream signaling, thereby contributing to the enhanced immune response of females. Bioessays 2011, 33, 791-802. [CrossRef]

43. Deng, X.; Berletch, J.B.; Nguyen, D.K.; Disteche, C.M. X chromosome regulation: Diverse patterns in development, tissues and disease. Nat. Rev. Genet. 2014, 15, 367-378. [CrossRef] [PubMed]

44. Matarrese, P.; Tieri, P.; Anticoli, S.; Ascione, B.; Conte, M.; Franceschi, C.; Malorni, W.; Salvioli, S.; Ruggieri, A. X-chromosomelinked miR548am-5p is a key regulator of sex disparity in the susceptibility to mitochondria-mediated apoptosis. Cell Death Dis. 2019, 10, 673. [CrossRef] [PubMed]

45. Tukiainen, T.; Villani, A.C.; Yen, A.; Rivas, M.A.; Marshall, J.L.; Satija, R.; Aguirre, M.; Gauthier, L.; Fleharty, M.; Kirby, A.; et al. Landscape of $X$ chromosome inactivation across human tissues. Nature 2017, 550, 244-248. [CrossRef] [PubMed]

46. Shireman, J.M.; Ahmed, A.U. Separate and not equal: Sex differences in JAM-A tumor suppression in glioblastoma. NeuroOncology 2020, 22, 1555-1556. [CrossRef]

47. Nilsson, S.; Makela, S.; Treuter, E.; Tujague, M.; Thomsen, J.; Andersson, G.; Enmark, E.; Pettersson, K.; Warner, M.; Gustafsson, J.A. Mechanisms of estrogen action. Physiol. Rev. 2001, 81, 1535-1565. [CrossRef]

48. Green, S.; Walter, P.; Kumar, V.; Krust, A.; Bornert, J.M.; Argos, P.; Chambon, P. Human oestrogen receptor cDNA: Sequence, expression and homology to v-erb-A. Nature 1986, 320, 134-139. [CrossRef]

49. Greene, G.L.; Gilna, P.; Waterfield, M.; Baker, A.; Hort, Y.; Shine, J. Sequence and expression of human estrogen receptor complementary DNA. Science 1986, 231, 1150-1154. [CrossRef]

50. Kuiper, G.G.; Enmark, E.; Pelto-Huikko, M.; Nilsson, S.; Gustafsson, J.A. Cloning of a novel receptor expressed in rat prostate and ovary. Proc. Natl. Acad. Sci. USA 1996, 93, 5925-5930. [CrossRef]

51. Mosselman, S.; Polman, J.; Dijkema, R. ER beta: Identification and characterization of a novel human estrogen receptor. FEBS Lett. 1996, 392, 49-53. [CrossRef]

52. Márquez, D.C.; Chen, H.W.; Curran, E.M.; Welshons, W.V.; Pietras, R.J. Estrogen receptors in membrane lipid rafts and signal transduction in breast cancer. Mol. Cell. Endocrinol. 2006, 246, 91-100. [CrossRef]

53. Levin, E.R.; Hammes, S.R. Nuclear receptors outside the nucleus: Extranuclear signalling by steroid receptors. Nat. Rev. Mol. Cell Biol. 2016, 17, 783-797. [CrossRef]

54. Marino, M.; Ascenzi, P. Membrane association of estrogen receptor alpha and beta influences 17beta-estradiol-mediated cancer cell proliferation. Steroids 2008, 73, 853-858. [CrossRef]

55. Gonzalez de Valdivia, E.; Broselid, S.; Kahn, R.; Olde, B.; Leeb-Lundberg, L.M.F. G protein-coupled estrogen receptor 1 (GPER1)/GPR30 increases ERK1/2 activity through PDZ motif-dependent and -independent mechanisms. J. Biol. Chem. 2017, 292, 9932-9943. [CrossRef]

56. Schiebler, T.H.; Danner, K.G. The effect of sex hormones on the proximal tubules in the rat kidney. Cell Tissue Res. 1978, 192, 527-549. [CrossRef]

57. Guido, C.; Panza, S.; Santoro, M.; Avena, P.; Panno, M.L.; Perrotta, I.; Giordano, F.; Casaburi, I.; Catalano, S.; De Amicis, F.; et al. Estrogen receptor beta (ERbeta) produces autophagy and necroptosis in human seminoma cell line through the binding of the Sp1 on the phosphatase and tensin homolog deleted from chromosome 10 (PTEN) promoter gene. Cell Cycle 2012, 11, $2911-2921$. [CrossRef]

58. Yang, Y.H.; Chen, K.; Li, B.; Chen, J.W.; Zheng, X.F.; Wang, Y.R.; Jiang, S.D.; Jiang, L.S. Estradiol inhibits osteoblast apoptosis via promotion of autophagy through the ER-ERK-mTOR pathway. Apoptosis 2013, 18, 1363-1375. [CrossRef]

59. Hsieh, D.J.; Kuo, W.W.; Lai, Y.P.; Shibu, M.A.; Shen, C.Y.; Pai, P.; Yeh, Y.L.; Lin, J.Y.; Viswanadha, V.P.; Huang, C.Y. 17beta-Estradiol and/or Estrogen Receptor beta Attenuate the Autophagic and Apoptotic Effects Induced by Prolonged Hypoxia Through HIF-1alpha-Mediated BNIP3 and IGFBP-3 Signaling Blockage. Cell Physiol. Biochem. 2015, 36, 274-284. [CrossRef]

60. Lin, C.W.; Chen, B.; Huang, K.L.; Dai, Y.S.; Teng, H.L. Inhibition of Autophagy by Estradiol Promotes Locomotor Recovery after Spinal Cord Injury in Rats. Neurosci. Bull. 2016, 32, 137-144. [CrossRef]

61. Wang, F.; Xiao, J.; Shen, Y.; Yao, F.; Chen, Y. Estrogen protects cardiomyocytes against lipopolysaccharide by inhibiting autophagy. Mol. Med. Rep. 2014, 10, 1509-1512. [CrossRef] 
62. Dong, L.; Wang, W.; Wang, F.; Stoner, M.; Reed, J.C.; Harigai, M.; Samudio, I.; Kladde, M.P.; Vyhlidal, C.; Safe, S. Mechanisms of transcriptional activation of bcl-2 gene expression by 17beta-estradiol in breast cancer cells. J. Biol. Chem. 1999, $274,32099-32107$. [CrossRef]

63. Hua, S.; Kallen, C.B.; Dhar, R.; Baquero, M.T.; Mason, C.E.; Russell, B.A.; Shah, P.K.; Liu, J.; Khramtsov, A.; Tretiakova, M.S.; et al. Genomic analysis of estrogen cascade reveals histone variant H2A.Z associated with breast cancer progression. Mol. Syst. Biol. 2008, 4, 188. [CrossRef]

64. Turei, D.; Foldvari-Nagy, L.; Fazekas, D.; Modos, D.; Kubisch, J.; Kadlecsik, T.; Demeter, A.; Lenti, K.; Csermely, P.; Vellai, T.; et al. Autophagy Regulatory Network-A systems-level bioinformatics resource for studying the mechanism and regulation of autophagy. Autophagy 2015, 11, 155-165. [CrossRef] [PubMed]

65. Felzen, V.; Hiebel, C.; Koziollek-Drechsler, I.; Reissig, S.; Wolfrum, U.; Kogel, D.; Brandts, C.; Behl, C.; Morawe, T. Estrogen receptor alpha regulates non-canonical autophagy that provides stress resistance to neuroblastoma and breast cancer cells and involves BAG3 function. Cell Death Dis. 2015, 6, e1812. [CrossRef] [PubMed]

66. Yang, Z.M.; Yang, M.F.; Yu, W.; Tao, H.M. Molecular mechanisms of estrogen receptor beta-induced apoptosis and autophagy in tumors: Implication for treating osteosarcoma. J. Int. Med. Res. 2019, 47, 4644-4655. [CrossRef] [PubMed]

67. Solakidi, S.; Psarra, A.M.; Sekeris, C.E. Differential subcellular distribution of estrogen receptor isoforms: Localization of ERalpha in the nucleoli and ERbeta in the mitochondria of human osteosarcoma SaOS-2 and hepatocarcinoma HepG2 cell lines. Biochim. Biophys. Acta 2005, 1745, 382-392. [CrossRef]

68. Solakidi, S.; Psarra, A.M.; Sekeris, C.E. Differential distribution of glucocorticoid and estrogen receptor isoforms: Localization of GRbeta and ERalpha in nucleoli and GRalpha and ERbeta in the mitochondria of human osteosarcoma SaOS-2 and hepatocarcinoma HepG2 cell lines. J. Musculoskelet. Neuronal Interact. 2007, 7, 240-245.

69. Yang, S.H.; Liu, R.; Perez, E.J.; Wen, Y.; Stevens, S.M., Jr.; Valencia, T.; Brun-Zinkernagel, A.M.; Prokai, L.; Will, Y.; Dykens, J.; et al. Mitochondrial localization of estrogen receptor beta. Proc. Natl. Acad. Sci. USA 2004, 101, 4130-4135. [CrossRef]

70. Cheng, S.B.; Quinn, J.A.; Graeber, C.T.; Filardo, E.J. Down-modulation of the G-protein-coupled estrogen receptor, GPER, from the cell surface occurs via a trans-Golgi-proteasome pathway. J. Biol. Chem. 2011, 286, 22441-22455. [CrossRef]

71. Totta, P.; Pesiri, V.; Marino, M.; Acconcia, F. Lysosomal function is involved in 17beta-estradiol-induced estrogen receptor alpha degradation and cell proliferation. PLoS ONE 2014, 9, e94880. [CrossRef]

72. Somasundaram, A.; Rothenberger, N.J.; Stabile, L.P. The Impact of Estrogen in the Tumor Microenvironment. Adv. Exp. Med. Biol. 2020, 1277, 33-52.

73. Orshal, J.M.; Khalil, R.A. Gender, sex hormones, and vascular tone. Am. J. Physiol. Regul. Integr. Comp. Physiol. 2004, 286, R233-R249. [CrossRef]

74. He, H.; Feng, Y.S.; Zang, L.H.; Liu, W.W.; Ding, L.Q.; Chen, L.X.; Kang, N.; Hayashi, T.; Tashiro, S.; Onodera, S.; et al. Nitric oxide induces apoptosis and autophagy; autophagy down-regulates NO synthesis in physalin A-treated A375-S2 human melanoma cells. Food Chem. Toxicol. 2014, 71, 128-135. [CrossRef]

75. Jiang, G.M.; Tan, Y.; Wang, H.; Peng, L.; Chen, H.T.; Meng, X.J.; Li, L.L.; Liu, Y.; Li, W.F.; Shan, H. The relationship between autophagy and the immune system and its applications for tumor immunotherapy. Mol. Cancer 2019, 18, 17. [CrossRef]

76. Straub, R.H. The Complex Role of Estrogens in Inflammation. Endocr. Rev. 2007, 28, 521-574. [CrossRef]

77. Pierdominici, M.; Maselli, A.; Colasanti, T.; Giammarioli, A.M.; Delunardo, F.; Vacirca, D.; Sanchez, M.; Giovannetti, A.; Malorni, W.; Ortona, E. Estrogen receptor profiles in human peripheral blood lymphocytes. Immunol. Lett. 2010, 132, 79-85. [CrossRef]

78. Pierdominici, M.; Maselli, A.; Locatelli, S.L.; Ciarlo, L.; Careddu, G.; Patrizio, M.; Ascione, B.; Tinari, A.; Carlo-Stella, C.; Malorni, W.; et al. Estrogen receptor beta ligation inhibits Hodgkin lymphoma growth by inducing autophagy. Oncotarget 2017, 8 , 8522-8535. [CrossRef]

79. Shepherd, R.; Cheung, A.S.; Pang, K.; Saffery, R.; Novakovic, B. Sexual Dimorphism in Innate Immunity: The Role of Sex Hormones and Epigenetics. Front. Immunol. 2021, 11, 604000. [CrossRef]

80. Kovats, S.; Carreras, E. Regulation of dendritic cell differentiation and function by estrogen receptor ligands. Cell. Immunol. 2008, 252, 81-90. [CrossRef]

81. Moulton, V.R. Sex Hormones in Acquired Immunity and Autoimmune Disease. Front. Immunol. 2018, 9, 2279. [CrossRef] [PubMed]

82. Ortona, E.; Delunardo, F.; Maselli, A.; Pierdominici, M.; Malorni, W. Sex hormones and gender disparity in immunity and autoimmunity. Ital. J. Gend. Specif. Med. 2015, 1, 45-50.

83. Dupuis, M.; Maselli, A.; Pagano, M.T.; Pierdominici, M.; Ortona, E. Immune response and autoimmune diseases: A matter of sex. Ital. J. Gend. Specif. Med. 2019, 5, 11-20.

84. Ozdemir, B.C.; Dotto, G.P. Sex Hormones and Anticancer Immunity. Clin. Cancer Res. 2019, 25, 4603-4610. [CrossRef]

85. Klein, S.L.; Morgan, R. The impact of sex and gender on immunotherapy outcomes. Biol. Sex Differ. 2020, 11, 24. [CrossRef]

86. Wei, Y.; Huang, C.; Wu, H.; Huang, J. Estrogen Receptor Beta (ERbeta) Mediated-CyclinD1 Degradation via Autophagy Plays an Anti-Proliferation Role in Colon Cells. Int. J. Biol. Sci. 2019, 15, 942-952. [CrossRef]

87. Kohli, L.; Kaza, N.; Coric, T.; Byer, S.J.; Brossier, N.M.; Klocke, B.J.; Bjornsti, M.A.; Carroll, S.L.; Roth, K.A. 4-Hydroxytamoxifen induces autophagic death through K-Ras degradation. Cancer Res. 2013, 73, 4395-4405. [CrossRef]

88. Marzagalli, M.; Casati, L.; Moretti, R.M.; Montagnani Marelli, M.; Limonta, P. Estrogen Receptor beta Agonists Differentially Affect the Growth of Human Melanoma Cell Lines. PLoS ONE 2015, 10, e0134396. [CrossRef] 
89. Chatterjee, S.J.; Pandey, S. Chemo-resistant melanoma sensitized by tamoxifen to low dose curcumin treatment through induction of apoptosis and autophagy. Cancer Biol. Ther. 2011, 11, 216-228. [CrossRef]

90. Yakimchuk, K.; Jondal, M.; Okret, S. Estrogen receptor alpha and beta in the normal immune system and in lymphoid malignancies. Mol. Cell. Endocrinol. 2013, 375, 121-129. [CrossRef]

91. Bustos, V.; Nolan, A.M.; Nijhuis, A.; Harvey, H.; Parker, A.; Poulsom, R.; McBryan, J.; Thomas, W.; Silver, A.; Harvey, B.J. GPER mediates differential effects of estrogen on colon cancer cell proliferation and migration under normoxic and hypoxic conditions. Oncotarget 2017, 8, 84258-84275. [CrossRef]

92. Konstantinopoulos, P.A.; Kominea, A.; Vandoros, G.; Sykiotis, G.P.; Andricopoulos, P.; Varakis, I.; Sotiropoulou-Bonikou, G.; Papavassiliou, A.G. Oestrogen receptor beta (ERbeta) is abundantly expressed in normal colonic mucosa, but declines in colon adenocarcinoma paralleling the tumour's dedifferentiation. Eur. J. Cancer 2003, 39, 1251-1258. [CrossRef]

93. Williams, C.; DiLeo, A.; Niv, Y.; Gustafsson, J.A. Estrogen receptor beta as target for colorectal cancer prevention. Cancer Lett. 2016, 372, 48-56. [CrossRef]

94. Campbell-Thompson, M.; Lynch, I.J.; Bhardwaj, B. Expression of estrogen receptor (ER) subtypes and ERbeta isoforms in colon cancer. Cancer Res. 2001, 61, 632-640.

95. Janik, M.E.; Belkot, K.; Przybylo, M. Is oestrogen an important player in melanoma progression? Contemp. Oncol. 2014, 18, 302-306. [CrossRef]

96. Mitkov, M.; Joseph, R.; Copland, J., 3rd. Steroid hormone influence on melanomagenesis. Mol. Cell. Endocrinol. 2015, 417, 94-102. [CrossRef]

97. Santen, R.J.; Santner, S.J.; Harvey, H.A.; Lipton, A.; Simmonds, M.; Feil, P.D.; Manders, E.; Davis, T.S. Marked heterogeneity of aromatase activity in human malignant melanoma tissue. Eur. J. Cancer Clin. Oncol. 1988, 24, 1811-1816. [CrossRef]

98. Mitchell, D.L.; Fernandez, A.A.; Garcia, R.; Paniker, L.; Lin, K.; Hanninen, A.; Zigelsky, K.; May, M.; Nuttall, M.; Lo, H.H.; et al. Acute exposure to ultraviolet-B radiation modulates sex steroid hormones and receptor expression in the skin and may contribute to the sex bias of melanoma in a fish model. Pigment Cell Melanoma Res. 2014, 27,408-417. [CrossRef]

99. de Giorgi, V.; Gori, A.; Grazzini, M.; Rossari, S.; Scarfi, F.; Corciova, S.; Verdelli, A.; Lotti, T.; Massi, D. Estrogens, estrogen receptors and melanoma. Expert Rev. Anticancer Ther. 2011, 11, 739-747. [CrossRef]

100. de Giorgi, V.; Mavilia, C.; Massi, D.; Gozzini, A.; Aragona, P.; Tanini, A.; Sestini, S.; Paglierani, M.; Boddi, V.; Brandi, M.L.; et al. Estrogen receptor expression in cutaneous melanoma: A real-time reverse transcriptase-polymerase chain reaction and immunohistochemical study. Arch. Dermatol. 2009, 145, 30-36. [CrossRef]

101. Ohata, C.; Tadokoro, T.; Itami, S. Expression of estrogen receptor beta in normal skin, melanocytic nevi and malignant melanomas. J. Dermatol. 2008, 35, 215-221. [CrossRef]

102. Schmidt, A.N.; Nanney, L.B.; Boyd, A.S.; King, L.E., Jr.; Ellis, D.L. Oestrogen receptor-beta expression in melanocytic lesions. Exp. Dermatol. 2006, 15, 971-980. [CrossRef]

103. de Giorgi, V.; Gori, A.; Gandini, S.; Papi, F.; Grazzini, M.; Rossari, S.; Simoni, A.; Maio, V.; Massi, D. Oestrogen receptor beta and melanoma: A comparative study. Br. J. Dermatol. 2013, 168, 513-519. [CrossRef]

104. Joosse, A.; de Vries, E.; Eckel, R.; Nijsten, T.; Eggermont, A.M.M.; Hölzel, D.; Coebergh, J.W.W.; Engel, J.; Munich Melanoma Group. Gender Differences in Melanoma Progression and Survival: Female patients have a decreased risk of metastasis. J. Investig. Dermatol. 2011, 131, 719-726. [CrossRef]

105. Marzagalli, M.; Montagnani Marelli, M.; Casati, L.; Fontana, F.; Moretti, R.M.; Limonta, P. Estrogen Receptor beta in Melanoma: From Molecular Insights to Potential Clinical Utility. Front. Endocrinol. 2016, 7, 140. [CrossRef]

106. Yakimchuk, K.; Hasni, M.S.; Guan, J.; Chao, M.P.; Sander, B.; Okret, S. Inhibition of lymphoma vascularization and dissemination by estrogen receptor beta agonists. Blood 2014, 123, 2054-2061. [CrossRef] [PubMed]

107. Yakimchuk, K.; Iravani, M.; Hasni, M.S.; Rhonnstad, P.; Nilsson, S.; Jondal, M.; Okret, S. Effect of ligand-activated estrogen receptor beta on lymphoma growth in vitro and in vivo. Leukemia 2011, 25, 1103-1110. [CrossRef]

108. Albain, K.S.; Unger, J.M.; Gotay, C.C.; Davies, J.S. Toxicity and survival by sex in patients with advanced non-small cell lung carcinoma (NSCLC) on modern Southwest Oncology Group (SWOG) trials. J. Clin. Oncol. 2007, 25, 7549. [CrossRef]

109. Hsu, L.H.; Liu, K.J.; Tsai, M.F.; Wu, C.R.; Feng, A.C.; Chu, N.M.; Kao, S.H. Estrogen adversely affects the prognosis of patients with lung adenocarcinoma. Cancer Sci. 2015, 106, 51-59. [CrossRef] [PubMed]

110. Rodriguez-Lara, V.; Pena-Mirabal, E.; Baez-Saldana, R.; Esparza-Silva, A.L.; Garcia-Zepeda, E.; Cerbon Cervantes, M.A.; Diaz, D.; Fortoul, T.I. Estrogen receptor beta and CXCR4/CXCL12 expression: Differences by sex and hormonal status in lung adenocarcinoma. Arch. Med. Res. 2014, 45, 158-169. [CrossRef] [PubMed]

111. Stabile, L.P.; Dacic, S.; Land, S.R.; Lenzner, D.E.; Dhir, R.; Acquafondata, M.; Landreneau, R.J.; Grandis, J.R.; Siegfried, J.M. Combined analysis of estrogen receptor beta-1 and progesterone receptor expression identifies lung cancer patients with poor outcome. Clin. Cancer Res. 2011, 17, 154-164. [CrossRef]

112. Niikawa, H.; Suzuki, T.; Miki, Y.; Suzuki, S.; Nagasaki, S.; Akahira, J.; Honma, S.; Evans, D.B.; Hayashi, S.; Kondo, T.; et al. Intratumoral estrogens and estrogen receptors in human non-small cell lung carcinoma. Clin. Cancer Res. 2008, 14, 4417-4426. [CrossRef]

113. Siegfried, J.M.; Hershberger, P.A.; Stabile, L.P. Estrogen receptor signaling in lung cancer. Semin. Oncol. 2009, 36, 524-531. [CrossRef] 
114. Ma, L.; Zhan, P.; Liu, Y.; Zhou, Z.; Zhu, Q.; Miu, Y.; Wang, X.; Jin, J.; Li, Q.; Lv, T.; et al. Prognostic value of the expression of estrogen receptor beta in patients with non-small cell lung cancer: A meta-analysis. Transl. Lung Cancer Res. 2016, 5, $202-207$. [CrossRef]

115. Mah, V.; Marquez, D.; Alavi, M.; Maresh, E.L.; Zhang, L.; Yoon, N.; Horvath, S.; Bagryanova, L.; Fishbein, M.C.; Chia, D.; et al. Expression levels of estrogen receptor beta in conjunction with aromatase predict survival in non-small cell lung cancer. Lung Cancer 2011, 74, 318-325. [CrossRef]

116. Skjefstad, K.; Grindstad, T.; Khanehkenari, M.R.; Richardsen, E.; Donnem, T.; Kilvaer, T.; Andersen, S.; Bremnes, R.M.; Busund, L.T.; Al-Saad, S. Prognostic relevance of estrogen receptor alpha, beta and aromatase expression in non-small cell lung cancer. Steroids 2016, 113, 5-13. [CrossRef]

117. Weinberg, O.K.; Marquez-Garban, D.C.; Fishbein, M.C.; Goodglick, L.; Garban, H.J.; Dubinett, S.M.; Pietras, R.J. Aromatase inhibitors in human lung cancer therapy. Cancer Res. 2005, 65, 11287-11291. [CrossRef]

118. Hershberger, P.A.; Vasquez, A.C.; Kanterewicz, B.; Land, S.; Siegfried, J.M.; Nichols, M. Regulation of endogenous gene expression in human non-small cell lung cancer cells by estrogen receptor ligands. Cancer Res. 2005, 65, 1598-1605. [CrossRef]

119. Siegfried, J.M.; Stabile, L.P. Estrongenic steroid hormones in lung cancer. Semin. Oncol. 2014, 41, 5-16. [CrossRef]

120. Zhang, G.; Yanamala, N.; Lathrop, K.L.; Zhang, L.; Klein-Seetharaman, J.; Srinivas, H. Ligand-independent antiapoptotic function of estrogen receptor-beta in lung cancer cells. Mol. Endocrinol. 2010, 24, 1737-1747. [CrossRef]

121. Qiu, L.; Hu, L.; Wang, H.; Li, J.; Ruan, X.; Sun, B.; Zhi, J.; Zheng, X.; Gu, L.; Gao, M.; et al. FATS regulates polyamine biosynthesis by promoting ODC degradation in an ERbeta-dependent manner in non-small-cell lung cancer. Cell Death Dis. 2020, 11, 839. [CrossRef] [PubMed]

122. Zhang, Z.; Jin, F.; Lian, X.; Li, M.; Wang, G.; Lan, B.; He, H.; Liu, G.D.; Wu, Y.; Sun, G.; et al. Genistein promotes ionizing radiation-induced cell death by reducing cytoplasmic Bcl-xL levels in non-small cell lung cancer. Sci. Rep. 2018, 8, 328. [CrossRef] [PubMed]

123. Jansson, M.D.; Lund, A.H. MicroRNA and cancer. Mol. Oncol. 2012, 6, 590-610. [CrossRef] [PubMed]

124. Kim, V.N.; Han, J.; Siomi, M.C. Biogenesis of small RNAs in animals. Nat. Rev. Mol. Cell Biol. 2009, 10, 126-139. [CrossRef] [PubMed]

125. Zeng, Y. Principles of micro-RNA production and maturation. Oncogene 2006, 25, 6156-6162. [CrossRef] [PubMed]

126. Pontecorvi, G.; Bellenghi, M.; Puglisi, R.; Care, A.; Mattia, G. Tumor-derived extracellular vesicles and microRNAs: Functional roles, diagnostic, prognostic and therapeutic options. Cytokine Growth Factor Rev. 2020, 51, 75-83. [CrossRef]

127. Sun, Y.; Xing, X.; Liu, Q.; Wang, Z.; Xin, Y.; Zhang, P.; Hu, C.; Liu, Y. Hypoxia-induced autophagy reduces radiosensitivity by the HIF-1alpha/miR-210/Bcl-2 pathway in colon cancer cells. Int. J. Oncol. 2015, 46, 750-756. [CrossRef]

128. Zhang, H.; Tang, J.; Li, C.; Kong, J.; Wang, J.; Wu, Y.; Xu, E.; Lai, M. MiR-22 regulates 5-FU sensitivity by inhibiting autophagy and promoting apoptosis in colorectal cancer cells. Cancer Lett. 2015, 356, 781-790. [CrossRef]

129. Colangelo, T.; Polcaro, G.; Ziccardi, P.; Muccillo, L.; Galgani, M.; Pucci, B.; Milone, M.R.; Budillon, A.; Santopaolo, M.; Mazzoccoli, G.; et al. miR-27a-calreticulin axis affects drug-induced immunogenic cell death in human colorectal cancer cells. Cell Death Dis. 2016, 7, e2108. [CrossRef]

130. Guo, W.; Wang, H.; Yang, Y.; Guo, S.; Zhang, W.; Liu, Y.; Yi, X.; Ma, J.; Zhao, T.; Liu, L.; et al. Down-regulated miR-23a Contributes to the Metastasis of Cutaneous Melanoma by Promoting Autophagy. Theranostics 2017, 7, 2231-2249. [CrossRef]

131. Yu, Y.; Xiang, N.; Lin, M.; Huang, J.W.; Zhang, J.; Cheng, B.; Ji, C. miR-26a Sensitizes Melanoma Cells to Dabrafenib Via Targeting HMGB1-Dependent Autophagy Pathways. Drug Des. Dev. Ther. 2019, 13, 3717-3726. [CrossRef] [PubMed]

132. Zhang, Y.; Gao, M.; Chen, L.; Zhou, L.; Bian, S.; Lv, Y. Licochalcone A restrains microphthalmia-associated transcription factor expression and growth by activating autophagy in melanoma cells via miR-142-3p/Rheb/mTOR pathway. Phytother. Res. 2020, 34, 349-358. [CrossRef] [PubMed]

133. Zhang, M.Y.; Calin, G.A.; Yuen, K.S.; Jin, D.Y.; Chim, C.S. Epigenetic silencing of miR-342-3p in B cell lymphoma and its impact on autophagy. Clin. Epigenet. 2020, 12, 150. [CrossRef] [PubMed]

134. Zhang, N.; Qiu, L.; Li, T.; Wang, X.; Deng, R.; Yi, H.; Su, Y.; Fan, F.Y. MiR-449a attenuates autophagy of T-cell lymphoma cells by downregulating ATG4B expression. BMB Rep. 2020, 53, 254-259. [CrossRef]

135. Zhang, W.; Dong, Y.Z.; Du, X.; Peng, X.N.; Shen, Q.M. MiRNA-153-3p promotes gefitinib-sensitivity in non-small cell lung cancer by inhibiting ATG5 expression and autophagy. Eur. Rev. Med. Pharmacol. Sci. 2019, 23, 2444-2452.

136. Rothschild, S.I.; Gautschi, O.; Batliner, J.; Gugger, M.; Fey, M.F.; Tschan, M.P. MicroRNA-106a targets autophagy and enhances sensitivity of lung cancer cells to Src inhibitors. Lung Cancer 2017, 107, 73-83. [CrossRef]

137. Zhang, Y.; Wang, J.; Hui, B.; Sun, W.; Li, B.; Shi, F.; Che, S.; Chai, L.; Song, L. Pristimerin enhances the effect of cisplatin by inhibiting the miR23a/Akt/GSK3beta signaling pathway and suppressing autophagy in lung cancer cells. Int. J. Mol. Med. 2019, 43, 1382-1394.

138. Guo, Q.; Zheng, M.; Xu, Y.; Wang, N.; Zhao, W. MiR-384 induces apoptosis and autophagy of non-small cell lung cancer cells through the negative regulation of Collagen alpha-1(X) chain gene. Biosci. Rep. 2019, 39, BSR20181523. [CrossRef]

139. Kim, E.R.; Chang, D.K. Colorectal cancer in inflammatory bowel disease: The risk, pathogenesis, prevention and diagnosis. World J. Gastroenterol. 2014, 20, 9872-9881. [CrossRef]

140. Wang, S.; Huang, Y.; Zhou, C.; Wu, H.; Zhao, J.; Wu, L.; Zhao, M.; Zhang, F.; Liu, H. The Role of Autophagy and Related MicroRNAs in Inflammatory Bowel Disease. Gastroenterol. Res. Pract. 2018, 2018, 7565076. [CrossRef] 
141. Edvardsson, K.; Nguyen-Vu, T.; Kalasekar, S.M.; Ponten, F.; Gustafsson, J.A.; Williams, C. Estrogen receptor beta expression induces changes in the microRNA pool in human colon cancer cells. Carcinogenesis 2013, 34, 1431-1441. [CrossRef]

142. Pandey, D.P.; Picard, D. miR-22 inhibits estrogen signaling by directly targeting the estrogen receptor alpha mRNA. Mol. Cell Biol. 2009, 29, 3783-3790. [CrossRef]

143. Krysko, D.V.; Garg, A.D.; Kaczmarek, A.; Krysko, O.; Agostinis, P.; Vandenabeele, P. Immunogenic cell death and DAMPs in cancer therapy. Nat. Rev. Cancer 2012, 12, 860-875. [CrossRef]

144. Li, X.; Mertens-Talcott, S.U.; Zhang, S.; Kim, K.; Ball, J.; Safe, S. MicroRNA-27a Indirectly Regulates Estrogen Receptor \{alpha\} Expression and Hormone Responsiveness in MCF-7 Breast Cancer Cells. Endocrinology 2010, 151, 2462-2473. [CrossRef]

145. Zhang, J.A.; Zhou, B.R.; Xu, Y.; Chen, X.; Liu, J.; Gozali, M.; Wu, D.; Yin, Z.Q.; Luo, D. MiR-23a-depressed autophagy is a participant in PUVA- and UVB-induced premature senescence. Oncotarget 2016, 7, 37420-37435. [CrossRef]

146. Amaravadi, R.K.; Lippincott-Schwartz, J.; Yin, X.M.; Weiss, W.A.; Takebe, N.; Timmer, W.; DiPaola, R.S.; Lotze, M.T.; White, E. Principles and current strategies for targeting autophagy for cancer treatment. Clin. Cancer Res. 2011, 17, 654-666. [CrossRef]

147. Beatty, G.L.; Gladney, W.L. Immune escape mechanisms as a guide for cancer immunotherapy. Clin. Cancer Res. 2015, 21, 687-692. [CrossRef]

148. Russell, R.C.; Yuan, H.X.; Guan, K.L. Autophagy regulation by nutrient signaling. Cell Res. 2014, 24, 42-57. [CrossRef]

149. Kroemer, G.; Marino, G.; Levine, B. Autophagy and the integrated stress response. Mol. Cell 2010, 40, 280-293. [CrossRef]

150. Cha, M.J.; Choi, E.; Lee, S.; Song, B.W.; Yoon, C.; Hwang, K.C. The microRNA-dependent cell fate of multipotent stromal cells differentiating to endothelial cells. Exp. Cell Res. 2016, 341, 139-146. [CrossRef]

151. Dika, E.; Patrizi, A.; Lambertini, M.; Manuelpillai, N.; Fiorentino, M.; Altimari, A.; Ferracin, M.; Lauriola, M.; Fabbri, E.; Campione, E.; et al. Estrogen Receptors and Melanoma: A Review. Cells 2019, 8, 1463. [CrossRef]

152. Kwiatkowski, A.V.; Gertler, F.B.; Loureiro, J.J. Function and regulation of Ena/VASP proteins. Trends Cell Biol. $2003,13,386-392$. [CrossRef]

153. Wang, H.; Wu, J.; Meng, X.; Ying, X.; Zuo, Y.; Liu, R.; Pan, Z.; Kang, T.; Huang, W. MicroRNA-342 inhibits colorectal cancer cell proliferation and invasion by directly targeting DNA methyltransferase 1. Carcinogenesis 2011, 32, 1033-1042. [CrossRef]

154. Sandbothe, M.; Buurman, R.; Reich, N.; Greiwe, L.; Vajen, B.; Gurlevik, E.; Schaffer, V.; Eilers, M.; Kuhnel, F.; Vaquero, A.; et al. The microRNA-449 family inhibits TGF-beta-mediated liver cancer cell migration by targeting SOX4. J. Hepatol. 2017, 66, 1012-1021. [CrossRef] [PubMed]

155. Stabile, L.P.; Lyker, J.S.; Gubish, C.T.; Zhang, W.; Grandis, J.R.; Siegfried, J.M. Combined targeting of the estrogen receptor and the epidermal growth factor receptor in non-small cell lung cancer shows enhanced antiproliferative effects. Cancer Res. 2005, 65, 1459-1470. [CrossRef] [PubMed]

156. Castellano, L.; Giamas, G.; Jacob, J.; Coombes, R.C.; Lucchesi, W.; Thiruchelvam, P.; Barton, G.; Jiao, L.R.; Wait, R.; Waxman, J.; et al. The estrogen receptor-alpha-induced microRNA signature regulates itself and its transcriptional response. Proc. Natl. Acad. Sci. USA 2009, 106, 15732-15737. [CrossRef] [PubMed]

157. Gomes, J.P.M.; Cardoso, C.R.P.; Varanda, E.A.; Molina, J.-M.; Fernandez, M.F.; Olea, N.S.; Carlos, I.Z.; Vilegas, W. Antitumoral, mutagenic and (anti)estrogenic activities of tingenone and pristimerin. Rev. Bras. Farmacogn. 2019, 21, 963-971. [CrossRef]

158. Levy, J.M.M.; Towers, C.G.; Thorburn, A. Targeting autophagy in cancer. Nat. Rev. Cancer 2017, 17, 528-542. [CrossRef]

159. Chen, H.T.; Liu, H.; Mao, M.J.; Tan, Y.; Mo, X.Q.; Meng, X.J.; Cao, M.T.; Zhong, C.Y.; Liu, Y.; Shan, H.; et al. Crosstalk between autophagy and epithelial-mesenchymal transition and its application in cancer therapy. Mol. Cancer 2019, 18, 101. [CrossRef]

160. Singh, S.S.; Vats, S.; Chia, A.Y.; Tan, T.Z.; Deng, S.; Ong, M.S.; Arfuso, F.; Yap, C.T.; Goh, B.C.; Sethi, G.; et al. Dual role of autophagy in hallmarks of cancer. Oncogene 2018, 37, 1142-1158. [CrossRef]

161. Qu, X.; Yu, J.; Bhagat, G.; Furuya, N.; Hibshoosh, H.; Troxel, A.; Rosen, J.; Eskelinen, E.L.; Mizushima, N.; Ohsumi, Y.; et al. Promotion of tumorigenesis by heterozygous disruption of the beclin 1 autophagy gene. J. Clin. Investig. 2003, 112, 1809-1820. [CrossRef]

162. Katayama, M.; Kawaguchi, T.; Berger, M.S.; Pieper, R.O. DNA damaging agent-induced autophagy produces a cytoprotective adenosine triphosphate surge in malignant glioma cells. Cell Death Differ. 2007, 14, 548-558. [CrossRef]

163. Marinkovic, M.; Sprung, M.; Buljubasic, M.; Novak, I. Autophagy Modulation in Cancer: Current Knowledge on Action and Therapy. Oxidative Med. Cell. Longev. 2018, 2018, 8023821. [CrossRef]

164. Buccarelli, M.; Marconi, M.; Pacioni, S.; De Pascalis, I.; D’Alessandris, Q.G.; Martini, M.; Ascione, B.; Malorni, W.; Larocca, L.M.; Pallini, R.; et al. Inhibition of autophagy increases susceptibility of glioblastoma stem cells to temozolomide by igniting ferroptosis. Cell Death Dis. 2018, 9, 841. [CrossRef]

165. Sui, X.; Chen, R.; Wang, Z.; Huang, Z.; Kong, N.; Zhang, M.; Han, W.; Lou, F.; Yang, J.; Zhang, Q.; et al. Autophagy and chemotherapy resistance: A promising therapeutic target for cancer treatment. Cell Death Dis. 2013, 4, e838. [CrossRef]

166. Roskoski, R., Jr. Properties of FDA-approved small molecule protein kinase inhibitors: A 2020 update. Pharmacol. Res. 2020, 152, 104609. [CrossRef]

167. Haas, N.B.; Appleman, L.J.; Stein, M.; Redlinger, M.; Wilks, M.; Xu, X.; Onorati, A.; Kalavacharla, A.; Kim, T.; Zhen, C.J.; et al. Autophagy Inhibition to Augment mTOR Inhibition: A Phase I/II Trial of Everolimus and Hydroxychloroquine in Patients with Previously Treated Renal Cell Carcinoma. Clin. Cancer Res. 2019, 25, 2080-2087. [CrossRef] 
168. Kobayashi, Y.; Yamada, D.; Kawai, T.; Sato, Y.; Teshima, T.; Yamada, Y.; Nakamura, M.; Suzuki, M.; Matsumoto, A.; Nakagawa, T.; et al. Different immunological effects of the molecular targeted agents sunitinib, everolimus and temsirolimus in patients with renal cell carcinoma. Int. J. Oncol. 2020, 56, 999-1013. [CrossRef]

169. Bustos, S.O.; Antunes, F.; Rangel, M.C.; Chammas, R. Emerging Autophagy Functions Shape the Tumor Microenvironment and Play a Role in Cancer Progression-Implications for Cancer Therapy. Front. Oncol. 2020, 10, 606436. [CrossRef]

170. Ge, Z.; Yu, H.; Yang, W.; Yang, J.; Liu, B.; Wang, X.; Liu, Z.; Liu, L. Development of Multi-Dimensional Cell Co-Culture via a Novel Microfluidic Chip Fabricated by DMD-Based Optical Projection Lithography. IEEE Trans. Nanobiosci. 2019, 18, 679-686. [CrossRef]

171. Parlato, S.; Grisanti, G.; Sinibaldi, G.; Peruzzi, G.; Casciola, C.M.; Gabriele, L. Tumor-on-a-chip platforms to study cancer-immune system crosstalk in the era of immunotherapy. Lab Chip 2021, 21, 234-253. [CrossRef] 